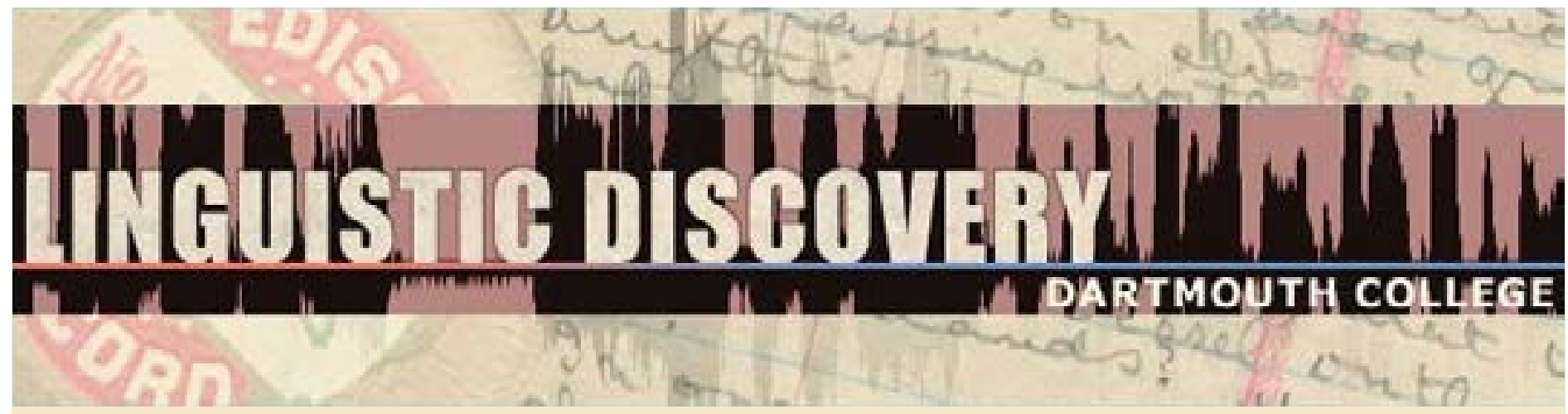

Volume 10

Issue 2 2012

\section{The Domari Language of Aleppo (Syria)}

Bruno Herin

Université Libre de Bruxelles

doi: 10.1349/PS1.1537-0852.A.412

url: http://journals.dartmouth.edu/cgi-bin/WebObjects/ Journals.woa/1/xmlpage/1/article/412 


\section{The Domari Language of Aleppo (Syria) \\ Bruno Herin \\ Université Libre de Bruxelles}

The goal of this paper is to shed light on an under-described variety of Domari, a very scarcely documented Indo-Aryan language spoken by the Dōm, who are often referred to as "the MiddleEastern Gypsies". Described as an archaic Indo-Aryan language, Domari is known to the scholarly community from a limited number of word lists dating back to the $19^{\text {th }}$ century and two partial descriptions based on a rather moribund dialect, the one spoken in Jerusalem. Apart from these sources, no reliable data are available about other varieties. The data presented in this paper come from an original field-work carried out in 2009 and 2010 amongst the Dōm community in the city of Aleppo in Northern Syria and are an important contribution to our knowledge of one of the very few old diasporic Indic languages spoken outside the Indian subcontinent.

\section{Introduction}

Domari is an Indic language spoken by the Dōm, commonly described as the "Gypsies" of the Middle-East. The Dōm are originally service-providing itinerant communities who left India at an early stage and spread across the Middle-East. The term Dōm is itself cognate with the Indian caste name $D \bar{o} m^{1}$ which is still widely used in India to designate a variety of peripatetic communities. ${ }^{2}$ Amongst the Indic languages spoken outside the Indian subcontinent, the most well-known and studied is Romani, the language of the European Roma. The Lom, located in Armenia and also in parts of Eastern Turkey, also spoke a fully-fledged Indic language but it has only survived as a lexicon within an Armenian matrix (Voskanian 2002). Domaaki and Parya are also diasporic Indic languages spoken outside or at the periphery of India but they remained typologically closer to Central Indo-Aryan languages. ${ }^{3}$ Although the historical links between Romani and Domari are still to a large extent obscure, it is now accepted that they are not sisterlanguages or even dialects of the same language. ${ }^{4}$

\footnotetext{
${ }^{1}$ The underdot symbol in Indian studies refers to retroflex consonants, commonly found in languages of the Indian subcontinent, whereas in Arabic studies, it refers to velarised consonants. All the Indo-Aryan roots are taken from Turner (1962-1966).

${ }^{2}$ See Beníšek 2009 for an historical account of the term dom/domba- in India. According to him, "it should be pointed out that the present-day doms do not represent a single caste or a homogenous group. In fact, the modern reflexes of the word domba- seem rather to be cover terms for a number of castes which may share certain features, such as being "low caste" and having a similar socio-cultural and economic profile. However, various dom groups in different parts of India may not share a common origin." (Beníšek 2009:349).

${ }^{3}$ They both retained to various degrees a partial ergative alignment, common in Indo-Aryan languages spoken in the Indian subcontinent, while Domari and Romani are both strictly accusative. For a recent account of Domaaki, see Weinreich (1999 \& 2008). For Parya, see Oranskij (1977) and also Payne (1997).

${ }^{4}$ Matras sums up the situation saying that "The linguistic affinity between Romani and Domari (and, as far as documented, Lomavren) might therefore be accounted for in terms of their shared ancient origin and subsequent similar social and geographical history, rather than as a token of continuous genetic ties in the form of a linguistic sub-branch within the Indo-Aryan languages." (Matras 2002:48).
} 
Very little is known about the history of the Dōm and much of what is stated about them relies on linguistic evidence. The language is known to be spoken in Palestine, Jordan, Lebanon, Syria, Turkey and probably also Iraq and Iran, although there is no direct evidence that Domari is still spoken in these last two countries (see below). The so-called Gypsies of Egypt (gağar in Modern Standard Arabic) and the Halab of Sudan both speak Arabic but kept a secret lexicon, partly based on Domari (Matras 2006). There are very few reliable figures about the number of Dōm, let alone the number of speakers. According to Matras (Matras 1999:4), the Jerusalem community does not exceed 600-700. Other figures are given by Meyer for Damascus about which he says that "In Sayyida Zaineb, the largest Dōm settlement, their number lies between 4000 and 10000" (Meyer 2004:76). The other Dōm population for which I was given estimations is that of the Diyarbakir province in eastern Turkey where their number is believed to be 14000 , of which 3000 are in the city of Diyarbakir itself (Adrian Marsh, p.c.). The Dōm community of Aleppo is probably one of the biggest in Syria and it is very plausible that their number exceeds a couple of thousand. In Syria, apart from Damascus and Aleppo, other groups are reported mainly in Homș and Latakieh. ${ }^{5}$

The Dōm are highly marginalised in the Syrian society and stereotypes associated with them are many. In Syria, they are referred to as Qurbāt ( 'orbāt in the dialect of Aleppo) or Qarač in the northern part of the country and Nawar elsewhere. The term Nawar, plural of Nūri, is also widely used in other parts of the Levant. These terms refer to various populations who mainly share a socio-economic profile. According to Meyer (2004:72), these groups used to adapt their migrations to the calendar of rural, nomadic and urban communities and according to this, fit quite well into the definition of peripatetic peoples. In Aleppo, the main (claimed) occupations are sieve-making, rudimentary dendistery and dancing (the so-called hağğiyyāt "female dancer" performing in the maqāșif, plural of maqșaf "cabaret"). In Syria, other occupations generally attributed to the Dōm are iron work, jewellery and the production of coffee mortars, while Dōm women focus on tattooing, fortune telling and begging (Meyer 2004:73). ${ }^{6}$ Every individual belongs to a clan or family. These are referred to as 'ašire (PL. 'ašāyir), a term mainly used in the context of Arabic traditional nomadic or rural life. Some of the names recorded are nāṣollāininn, ${ }^{7}$ barǧōlyīn, qādoḷāainn, malhamīn, zētqayyīn and also qurbāt iššs̄àm (literally "Dōm of Damascus"). The zêtqayyīn are also called by the Arabic name akkālīn zèt "oil eaters". The

\footnotetext{
${ }^{5}$ I have witnessed myself communities in the province of Iskenderun, which now belongs to Turkey but used to be part of Syria until 1939. This was also confirmed by a Dōm informant I recorded in Beirut (Lebanon) in July 2011, originally from Sarāqib, in the governorate of Idlib (a Syrian region in the immediate vicinity of Iskenderun).

${ }^{6}$ Also according to Meyer (2004:74), the various groups covered by the term Nawar are the Dōm, Turkmen (Sunni and Shia), Abtal, Alban, Akrad and Kaoli. He reports that the Turkmens and the Abtal speak Turkish, the Akrad speak Kurdish, the Alban speak "Quarnaqut [sic!]" (hypercorrection for Albanian, 'arna'ut, Jérôme Lentin, p.c.) and the Kaoli speak a Persian dialect. As for the language of the Dōm, he writes "Domané", a term I never came across. While the Turkmen probably speak a Turkic language, more in-depth fieldwork is needed to make any decisive statement about the languages spoken by these groups.

${ }^{7}$ The clan name nāṣollạāin obviously comes from Arabic Nāṣir (Arabic proper noun) + lar (Turkish plural suffix) + in (Domari plural marker). Quite normally, /r/ assimilates to $/ \mathrm{l} /$, resulting in gemination of $/ \mathrm{l} /$. An interesting feature is also the velarisation /11/: /l! /.

${ }^{8}$ Same as above: $q \bar{a} d i r-l a r-\bar{n} n$
} 
nāṣı!ḷārinn and qādollāāinn are also referred to by their Arabic name nawāṣra and qawādra, applying the pattern $\mathrm{CaC} \overline{\mathrm{a} C \mathrm{Ca}}$ traditionally used in Arabic to designate clans or groups.

The language spoken by the Dōm is traditionally called Domari amongst the scholarly community. The name appears for the first time in a series of articles published by Macalister in the early $20^{\text {th }}$ century in which he describes the variety spoken in Palestine (Macalister 1914) and has since been used indifferently by scholars (Matras 1999:4). The Dōm of Aleppo do not call their language domari, but dōmvārí (expectedly stressed on the last syllable), which may occur in collocation with ğib "language": dōmvārī ğib "Domari language". " An attractive etymology for dōmvāri is the suffixation of the Old Indo-Aryan root *vari "speech, language" ethnonym Dōm. Dōmvārī would thus originally mean "speech of the Dōm". However, this morpheme does not seem to be productive anymore in Domari, although more research is needed to confirm this claim. It would then remain to be explained why two morphemes with the same meaning co-occur: vari and ğib. A possible account is that the two formatives dōm and vari lexicalised, and that the suffix vari lost any productivity, allowing the new lexeme to occur in collocation with ğib. The formative vari is also found in Turkish where it appears as a derivational suffix that attaches to nouns to derive adjectives. ${ }^{11}$ Göksel \& Kerslake (2005:62) notes that this suffix of Persian origin tends to fall out of use. Since derivational suffixes are easily borrowed, it may simply have been copied from Turkish or a variety of Iranian with which Domari was in contact. It is still unclear where the term "Domari" comes from but a possible explanation is that what Macalister heard was not dōmvārī but dōmwārī. The approximant [v] is specific to the dialect of Aleppo and data available from other dialects indicate that this phoneme is usually realised $[\mathrm{w}]$. The proximity of $[\mathrm{m}]$ and $[\mathrm{w}]$ may lead to assimilation or the elision of either $[\mathrm{m}]$ or $[\mathrm{w}]$, making it sound like $d \bar{o} w a \bar{r} r i \sim d \bar{o} m a \bar{r} i \overline{.}$ Strangely enough though, Macalister transcribes it dōmári in his lexicon, suggesting that the word is stressed on the second syllable, whereas dōmvārí is clearly stressed on the last syllable. For the sake of clarity and whatever the truth is, the term Domari is now well established and will be maintained in the present work.

Data about Domari are extremely scarce. The only variety that has been properly investigated is the one spoken in Jerusalem. Until recently, the main source of much of what had been written about Domari was Macalister's description first published in a series of articles in the Journal of the Gypsy Lore Society at the beginning of the $20^{\text {th }}$ century and subsequently compiled in a single volume (Macalister 1914). Since Macalister, the only scholar who carried out original fieldwork is Yaron Matras (1999). He investigated the same community that was the object of Macalister's study. Other available material dates back from the $19^{\text {th }}$ century and consists mainly of word lists. Chronologically, the first article of interest is Pott (1846) in which he discusses data collected in the vicinity of Beirut. Overall, Aleppo Domari seems closer to this dialect than to Palestinian Domari. ${ }^{12}$ Newbold's article (Newbold 1856) entitled "The Gypsies of Egypt"

\footnotetext{
${ }^{9}$ As far as I know, the name first appears in Arabic in Al-Jibāwī (2006:13) as ضوم واري, which can be transliterated dōmwārī.

${ }^{i 0}$ Turner (1962-1966:660, lemma 11327) and Zoller (2005:16).

${ }^{11}$ Göksel \& Kerslake (2005:62) provides only two examples: gangstervari "gangsterlike" and Amerikanvari "American-like".

${ }^{12}$ Amongst the lexical items from Pott I couldn't find traces of in Palestinian Domari, one finds chaghâ "boy" (Aleppo čăgãa) or $\hat{i} c h$ "foot" (Aleppo qüc). This last item is interesting as it suggests that the Domari dialect of Beirut
} 
presented material collected in northern Syria, more specifically in Aleppo and Antioch, and also in Iraq. ${ }^{13}$ Worth of interest is also Paspatti's work (Paspatti 1873) whose primary focus was the Romani dialects spoken in the European parts of the Ottoman Empire and in which he also discusses data from Domari probably collected in Eastern Anatolia. Most of the examples and the lexical items he gives are also to be found in the contemporary dialect of Aleppo. ${ }^{14}$ The short article of Francis Groome (1891) presents data collected in Iran and in Damascus. The Iranian word list apparently originates from Tabriz and is a reprint from William Ouseley (1823) who was traveling in the region in 1812. The language is obviously Domari and this is clear evidence that it was once spoken in what is now Iran. The Damascene word-list seems to have been collected a couple of years earlier, around 1881. Although the transcription of the Damascene data seems rather erratic, the language is quite close to what I recorded in Aleppo. ${ }^{15}$ Another source is Patkannoff's article in which he gives words of what he calls "the dialects of the Transcaucasian Gypsies” (Patkannoff 1907/1908). ${ }^{16}$ Macalister's description (Macalister 1914) is the first attempt to document the essentials of Domari grammar as spoken in Palestine. He based his work on a single speaker whom he asked to translate into Domari Arabic sentences and texts. This methodology in modern descriptive linguistics would probably be cautioned against but he nevertheless managed to collect a significant lexicon and to provide a rather accurate grammatical sketch of Palestinian Domari. Matras' study (Matras 1999) is a follow-up of Macalister's and documents the language as it is used now, supplementing what had passed unnoticed or not fully understood by Macalister. The overall picture is a rather moribund language, deeply influenced by Arabic. Matras estimates that only twenty per cent of the Dōm population in Jerusalem maintained an active use of Domari in their household, mostly elders

had already undergone the phonetic change attested in the contemporary dialect but also in urban Arabic dialects of the Levant and cross-linguistically, that is the passage from uvular [q] to laryngeal [?]: Aleppo qāyī̌s "food" vs Beirut ' $\bar{a} y \bar{i} \breve{s}$. As far as grammaticall material is concerned, one reads șâ "all" (Aleppo sã), amin "we" (Aleppo amin),

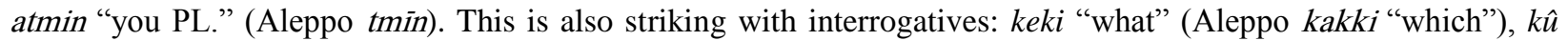
"who" (Aleppo $k \bar{o}$ ), keita "where" (Aleppo kêta), ksei "why" (Aleppo ksê). The same goes for the copula and the imperfect marker -a: keita stûra "where were you" (Aleppo kēta štōrā(ši)).

${ }^{13}$ It consists mainly of a list of lexical items. Most of them are also found in Aleppo Domari. An interesting feature is the western Iranian preposition $z_{-}^{-}$"from" that appears in some sentences (Newbold 1856: 312): ma z'Antuki eiroom "I came from Antioch". This preposition is still in use today.

${ }^{14}$ Paspatti calls the Dom "Tchingianés asiatiques". He also gives items in what he calls the language of the "Tchingianés de Tokat". A closer look is needed to confirm whether this is a form of Lomavren.

${ }^{15}$ An interesting feature is the extent of fusion with Arabic. The Aleppo variety also draws heavily on Arabic but one can see things that usually do not appear in Aleppo like the Arabic preposition min "from": minzaytta "from here" (Aleppo zēta). Also striking is the co-occurrence of Arabic min and Iranian z- in Damascus. The same remark goes for the Arabic conjunction $W$ - "and" that made its way into Damascene Domari: heyta wa hota "here and there". This never appears in Aleppo where la- is used, together with Kurdish = ši. Matras $(1999: 2,27)$ considers these items to originate from Beirut. The problem may arise from the ambiguity of Groome (1891:25) who writes that this list was sent to him "by Miss G. G. Everest of Beyrout, who had got it from a friend at Damascus".

${ }^{16}$ The sentences he gives in the "Karači dialect" (Patkannoff 1907/1908: 260-264), although some words can be recognised, are extremely puzzling. My opinion is that this language could hardly be called Domari and should be considered another idiom. A striking syntactical difference between Domari and the language documented by Patkannoff is the possessive pronouns. In Patkanoff's material, these may appear as free morphemes placed prenominally: ame dikom teri laftihi "we saw your daughter". The words in this sentence are easily identifiable: ame "we" (as in Palestinian Domari), dikom "we saw" (Aleppo Domari dak- lak- "see, find"), teri "your" (Aleppo Domari tor- the oblique form of tō "you") and laftihi "daughter" (Aleppo Domari lāftī "girl"). 
(Matras 1999:4). The question of language maintenance in other communities is rather tricky. When asked if people usually spoke Domari to their children, my informants generally answered positively. I also witnessed mothers addressing their children in Domari. I also recorded an eight year old boy who seemed fully competent in Domari. It would then seem that the dialect of Aleppo is in a good shape, although a more in-depth sociolinguistic study would be needed in order to assess the level of endangerment of the language. According to this, it seems that any general statement about language maintenance amongst Dōm communities is simply impossible and premature, as situations seem to vary greatly from one location to another. As far as multilingualism is concerned, all the Dōm in Aleppo are proficient in Arabic. ${ }^{17}$ It should be added as well that the neighbourhood I worked in (Ašrafiyye) is populated by Dōm and Kurds and that Kurdish is still a contact language of Aleppo Domari.

Apart from the variety spoken in Palestine, which is on the verge of extinction, and the few sources dating back to the $19^{\text {th }}$ century, virtually nothing is known about other varieties of Domari. The present work aims at filling this gap by documenting some structures of an undescribed dialect of Domari, that of Aleppo. This is by no means an exhaustive study and only a couple of features will be discussed here. A more lengthy and comprehensive fieldwork will be needed to provide a more thorough description. A first series of recordings with two speakers -a man and a woman in their early thirties- was made in the summer 2009 that consisted mainly of some lexical items and paradigms. I was able to go back to Aleppo in summer 2010 where I recorded more speakers, a man in his fifties and his son, and two other young men in their twenties. Most of the time was devoted to filling in a linguistic questionnaire developed by Yaron Matras and Viktor Elšik and initially designed for Romani dialects (Matras \& Elšík 2001). ${ }^{18}$ I was also able to record short excerpts of spontaneous speech. All the recordings were transcribed and analysed. What follows is the outcome of this analysis. Due to the rather small size of the corpus, everything that is stated here should be considered provisional until more indepth fieldwork is done.

\section{Sound System}

\subsection{Vowels}

Although more data is needed in order to establish the phonological system of Domari on the basis of minimal pairs, phonemic contrast seems to be available only between long vowels. These are $/ \overline{\mathrm{a}} /, / \overline{\mathrm{a}} /, / \overline{\mathrm{i}} /, / \overline{\mathrm{u}} /, / \overline{\mathrm{e}} /$ and $/ \overline{\mathrm{o}} /$. In plain context, the main allophones of these long vowels are respectively [æ:] (pāpî́r [pæ:'pi:r] "grand-father”), [a:] pāsóm [pa:'so:m] "at me, at my place”, [i:] psīk [psi:k] “cat”, [u:] kūkár [ku:'kær] “cock”, [e:] čēzók [tfe:'zək] “child”, [o:] ōšt [o:St] “lip”. The vowel /ē/, although the main realisation is [e:], was also recorded [I:] in items like [kss:] ( [kse:]) "why" and [kı:tæ] ( [ke:tæ]) "where". In final position, a nasalised reflex of / $\overline{\mathrm{a}} /$ appears:

\footnotetext{
${ }^{17}$ They mostly speak the dialect of Aleppo. One of my informants had also features traceable to Iraqi Arabic. I was also struck by the fact that most of them kept the uvular realisation of /q/, whereas in the dialect of Aleppo etymological /q/ is mostly realised as a glottal stop. The [q] reflex is however kept in some villages around Aleppo.

${ }^{18}$ I am grateful to Yaron Matras for sending me an electronic version of the questionnaire. It can also be found online at romani.humanities.manchester.ac.uk/rms/browse/phrases/phraselist.
} 
tətấ [tə'tã:] "he gave", lavrấ [læ'vrã:] "tree”, drōngấ [dro:n'gã:] "long, big”. This may be a pausal phenomenon. This is further suggested by the behaviour of the morpheme sã "all", clearly realised with nasalisation when followed by a pause: čāgēm sã [tfæ:ye:m sã:] "all my kids"; but otherwise realised [a:] when other morphological material is suffixed: $s \bar{a}-\bar{e}-m \bar{a}$ [sa:e:mæ:] "all of us". As far as short vowels are concerned, one finds a great deal of variability and a strong tendency to centralisation towards [ə] is observed, especially in rapid speech. This parallels what usually happens in sedentary Northern Levantine Arabic dialects in which phonemic contrast between the three inherited short vowels /a/, /i/ and /u/ tends to be reduced to /a/ and /a/ (or /a/ and $/ \mathrm{u} /$ ). Such a loss of phonemic contrast between short vowels is also suggested by the tendency to elision in unstressed positions: ahlōm korí ahlōm krí "the house of my family", čorí ̌̌rí "knife", māmōm qor "my cousin (the son of my uncle)" but qr-ōm "my son". One may posit a symmetrical system of long and short vowels and recognise the following inventory of short vowels: /a/, /a/, /i/, /u/, /e/ and /o/. However, due to centralisation, the following realisations are most often encountered: $[\ni],[\dot{\mathrm{j}}],[\mathrm{H}]$ and $[\Theta]$. This is further exemplified when comparing some of the items given by Matras (1999:9) in I.P.A.: Jerusalem [man'us] "person" vs. Aleppo [mə'nəs] "husband", Jerusalem [lakı'dom, laka'dom, lake'dom] "I saw" vs. Aleppo [lakər'do:m dakərdo:m] "I saw I found". The vowel [i] was mostly recorded in final stressed closed

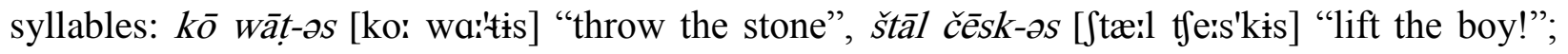
and also in loans from Turkish: yēldoz [je:l'diz] "star" (< Turkish yIldIz "star"). Central rounded

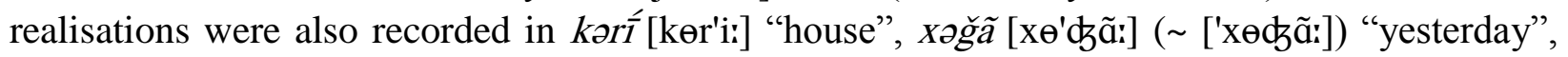
gəldvāní [geldvæ:'ni:] "sweets". It is however premature to assign these various allophones to their phonemes. As said above, more data is needed to fully describe the vowel system.

\subsection{Consonants}

\begin{tabular}{|c|c|c|c|c|c|c|c|c|c|c|}
\hline & Bilabial & Labiodental & Dental & Alveolar & Postalveolar & Palatal & Velar & Uvular & Pharyngeal & Glottal \\
\hline Nasal & $\mathrm{m}$ & & & $\mathrm{n}$ & & & & & & \\
\hline Plosive & $\begin{array}{l}\mathrm{p} \\
\mathrm{b}\end{array}$ & & & $\begin{array}{l}\mathrm{t} \\
\mathrm{d}\end{array}$ & & & $\begin{array}{l}\mathrm{k} \\
\mathrm{g}\end{array}$ & $q$ & & ()$\left.^{\prime}\right)$ \\
\hline Fricative & & $\mathrm{f}$ & & $\begin{array}{l}\mathrm{S} \\
\mathrm{Z}\end{array}$ & $\check{S}$ & & $\begin{array}{l}\mathrm{x} \\
\dot{\mathrm{g}}\end{array}$ & & h & $\mathrm{h}$ \\
\hline Velarised & & & & $\begin{array}{l}\mathrm{t} \\
\mathrm{d} \\
\mathrm{z}\end{array}$ & & & & & & \\
\hline Affricate & & & & & $\begin{array}{l}\check{\mathrm{c}} \\
\check{\mathrm{g}}\end{array}$ & & & & & \\
\hline Approximant & (w) & $v$ & & & & $\mathrm{y}$ & & & & \\
\hline Tap & & & & $\mathrm{r}$ & & & & & & \\
\hline Lateral & & & & 1 & & & & & & \\
\hline
\end{tabular}

Table 1: Inventory of Consonants 
The laryngeal $/ \mathrm{h} /$ in the inherited component is usually elided and surfaces only in (very) careful speech. It has been maintained systematically only in the demonstrative $h \bar{a}$. Although only marginally, /h/ may undergo elision in material borrowed from Arabic. fommōme "I understand" (< Arabic fham "understand"). Otherwise, /h/ is normally maintained in Arabic and Kurdish items: dahn dāhín kar- "to paint", har "each", hazz "still". The pharyngeals /ḥ/ and // are of course mainly found in items borrowed from Arabic, but also from Kurdish: hawt $\sim$ haft "seven", hašt "eight", mo ōri "ant". Interestingly, the pharyngeal / $/$ was also recorded in the word 'ărd "earth". The word for "coffee" is borrowed from Arabic but appears with / h/: qahwa "coffee" (< Arabic qahwa). The uvular /q/ is common in loanwords from Arabic, Kurdish or

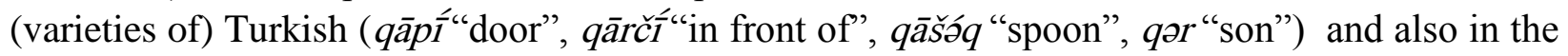

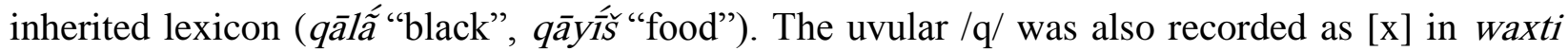
"when", probably from Kurdish (initially from Arabic waqt "time"). ${ }^{19}$ This conjunction however was not recognised by all the informants. The voiceless velar / $\mathrm{x} /$ is very common and appears in all layers of the language: taxt "bed" (< colloquial Arabic taxt, originally a loan from Persian), xašt "hand", xāzóme "I laugh". The voiced velar / $\dot{\mathrm{g}} /$ appears mainly in the Arabic component: gabre "dust", galat "wrong", $\dot{g} \bar{e} r$ "other". It was also recorded in čầga "child", probably borrowed from Kurdish. In rapid speech, voiceless consonants may undergo voicing: mə-gaztí

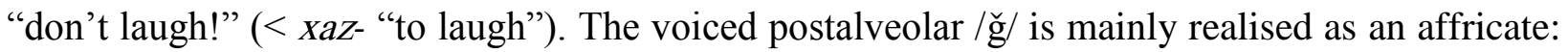
ǧāftã "groom", áğã "today", ğānóme "I know". It may alternate with the fricative reflex [ž] in

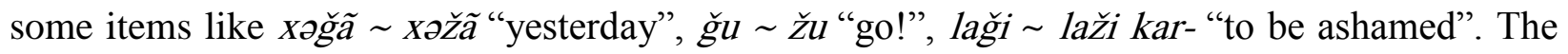
fricative also appears commonly in items borrowed from Arabic: sižn "prison", miḥtāž =ištōme "I need". This, surprisingly, cannot be attributed to an influence from the Arabic dialect of Aleppo because in that variety, etymological / $/$ / is mostly realised as an affricate. The voiceless affricate /č/ is quite stable and no instances of de-affrication towards [ ̌̌s] were recorded. In some cases, $[\check{c}],\left[\mathrm{t}^{\mathrm{y}}\right]$ and $[\mathrm{t}]$ seem to be in free variation, as in the following variants: lāfty $\overline{1} \sim \operatorname{la} \bar{a}_{\bar{c}} \bar{i} \sim \operatorname{la} f t \overline{1}$ "girl". Such a variation is also common in the subjunctive extension -č-: pārčom pārt" om "(that) I come back", $k \bar{a}(h) \bar{o} c ̌ o m ~ \sim ~ k \bar{a}(h) \bar{o} t$ 'om "I will be(come)". It must be added however, that $[\check{c}]$ and $\left[\mathrm{t}^{\mathrm{y}}\right]$ are not in free variation as speakers consistently use either one variant or the

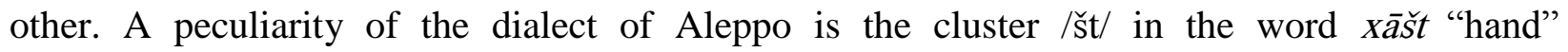
(Palestinian Domari xast). The velarised consonants / $\mathbf{d} /, / \mathrm{t} /$ and /ẓ/ (the underdot symbol refers to velarisation, not retroflexion) are commonly found in items borrowed from Arabic: faddil kar"prefer" (Arabic fadḍl "he preferred", matbax-ó-mã "in the kichen" (< Arabic matbax "kitchen"), tâ̄wlấ "table" (< Arabic țâwle "table"), zonn (h)ōme "I think" (< Arabic zann "he thought"). Velarised realisations were also recorded in the following items: $p \bar{t} t$ "belly" (< IndoAryan pētta "belly"), wāt "stone" (< Indo-Aryan varta "round stone"), tollãa "fat" (< Indo-Aryan sthūlâ). Peculiar to the dialect of Aleppo is the approximant /v/: vāl "hair", vāy "air", vyār "city, market", lvā kar- "open". The allophone [w] appears in the vicinity of back vowels: wāt [wa:t] "stone", kōwirōm "I fell", kā ğirsāwōča "You will get married", awāsārr "summer"; and in loans from Arabic : sēwi "straight", '‘̄win kar-"help", lwī kar-"bend". This seems to suggest that one should distinguish between [w] as allophone of $/ v /$ and $/ \mathrm{w} /$ as a distinct phoneme. An interesting minimal pair to contrast $/ \mathrm{v} /$ and $/ \mathrm{b} /$ appears in the following prepositions: $b \bar{e}$ "with

\footnotetext{
${ }^{19}$ The shift from /q/ to /x/ in waqt "time" is also attested in some dialects of Arabic (Jérôme Lentin, p.c.).
} 
(instrumental)" vs. $v \bar{e}^{-}$"without". The former is probably replicated from Arabic bi- "in, with", while the latter must have been borrowed from Kurdish (< bê "without"). The approximant $/ v /$ is also used as an epenthetic consonant to avoid hiatus: $k \bar{a}$ (future marker) pčā- "ask" $+-\bar{a}$ (2.SG. subjunctive) $\rightarrow k \bar{a} p c \bar{c} \bar{a} \bar{a}$ "you will ask". The phoneme /r/ is mostly realised as an alveolar tap (I.P.A. [r]).

\subsection{Stress}

Judging by the recorded data, stress assignment in Aleppo Domari is the same as in Palestinian Domari: it falls on the last syllable of the phonological word: kandargî́ "rabbit", korvók "worm", xōrānók" waist". Stress on the first syllable was recorded in certain adverbs of time: áğãa "today", sóbã "tomorrow" and xóğã "yesterday", although the last two items may also be stressed on the

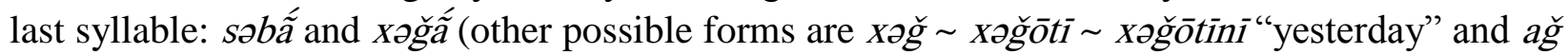
ağôti ağōtīni "today"). When morphological material is suffixed to nominal roots, only Layer I case markers (accusative -əs, oblique - $ə$ and accusative/oblique -ən, see below for a discussion of Layer I and II) and bound pronouns are part of the domain of stress: kōmár "firewood"+ -əs (accusative marker) $\rightarrow$ kōmar-ós, bén "sister" + -ōr $\rightarrow$ bèn-ór "your sister". Layer II markers are never stressed: pānd-ó-tã "on the road" (path-OBL-SUP). As far as bound pronouns are concerned, one observes that the formative /ān/ used to mark the plural remains out of the domain of stress: $p \bar{a}$ pās-óm-ān "come to our place" (come AD.1PL). This may explain

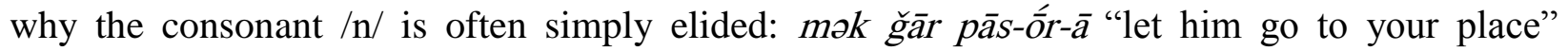
(let.IMP go.SUBJ.3SG at-1-PL). The copula can be stressed when it appears right after the lexical root: hanā grān=é "this is heavy" (DEM heavy=COP). It remains outside the domain of stress when additional material is inserted between the root and the copula: $k$ rry-ó-mān $=e^{\text {"it's }}$ our house" (house-SG-1PL=COP). This seems to suggest that the maximum stress shift is one syllable to the right of the lexical root. This is further evidenced with verbal roots where the suffixation of morphological material triggers a stress shift of one syllable to the right: tōnde "they put" $+-s\left(3^{\text {rd }}\right.$ person singular object bound pronoun $) \rightarrow$ tôndóse "they put it". An exception appears with verbs in the imperfective marked with the negation marker $n$-, in which case stress falls on the last syllable of the verbal word: n-ğān-mə-sān-é "I don't know them" (NEGknow.IMPFV-SUBJ.1SG-OBJ.3PL-CM), n-mangīšt-ōr-s-é “you don't want it" (NEGwant.PROG-SUBJ.2SG-OBJ.3SG-CM, see below for a short discussion of negation strategies). Stress also falls on the so-called remoteness marker $-\bar{a}(\check{S} i)$ (see below for a discussion of the marker -ă): $k$ əry-ə́- $m=$ ištōre (house-OBL-IN=COP.2SG) "you are home" vs. kəry-ə-m n-ištōr$\bar{a} \hat{s} i$ (house-OBL-IN NEG-COP.2SG-RM) "you were not home". In the perfective, $n$ - drags stress on the first syllable: āyrốm "I came" vs. nérōm "I didn't come". Items borrowed from Arabic are integrated into the Domari stress pattern: tạwlẫ "table" (< Arabic tấwle), kursiyyấ "chair" (< Arabic kursì), dīwāniyyẫ "bench" (< Arabic dīwāniyye). Unlike what is reported in Palestinian Domari (Matras 1999:14), even proper nouns are integrated into the Domari pattern: Arabic hásna (female name) vs. Domari ḥəsná. 


\section{Morphology}

\subsection{Free pronouns}

Domari has a set of free pronouns and another of bound pronouns.

\begin{tabular}{|l|l|l|}
\hline & Singular & Plural \\
\hline 1 & amā & amīn \\
\hline 2 & tō $;$ tor- & tmīn \\
\hline 3 & pānğ $\bar{i}$ & \\
\hline
\end{tabular}

Table 2: Free Pronouns

The 3.PL * panğyān, attested in Palestinian Domari (pandžan, see Matras 1999: 27) never appears in the corpus. However, it is very plausible that it exists and was simply not recorded. Although pānğ $\bar{l}$ is well attested, third person is most often expressed by demonstratives used pronominally. The recorded forms for the singular are the following: $h a n(\bar{a})$ (proximal) and $h(a) n \bar{u}$ (distal). The singular forms ōron hanōron were also recorded and may be competing distal forms. In the plural, the following forms were recorded: êrīn $\sim$ hanèrin (proximal) and ōrīn $\sim$ hanōrīn (distal). More data are necessary in order to see whether these inflect for case and gender.
a. $h n \bar{u}$
$n$ - ğăšte
kərī
that NEG-go.PROG.3SG house

"(S)he doesn't want to go home"
b. ōrinn kēlende tạ̄bāni
those play.IMPFV.3PL foot-ball
"They play foot-ball"

There is also a set of marked forms for the $1^{\text {st }}$ and $2^{\text {nd }}$ persons (Table 3 )

\begin{tabular}{|l|l|l|}
\hline & Singular & Plural \\
\hline 1 & amēn & amārīn \\
\hline 2 & tēn & tmārīn \\
\hline
\end{tabular}

Table 3: Marked Free Pronouns

Their use seems to be conditioned by topicalisation, as evidenced in (2).

(2) a. tēn vērōr čă $\bar{g}$ - $\supset S$

2SG hit.PFV.2SG boy-ACC

"You are the one who hit the boy" 


\section{b. tmārīn sậ-ēra nạmạ̄z karse \\ 2PL all-2PL pray.IMPFV.2PL \\ "All of you, you are praying"}

The suffixation of Layer II case markers to free pronouns appears to be a marginal strategy in comparison with the attachment of bound pronouns to preposition-like formatives. This was however recorded with amā, tō, amīn and tminn: (a)mā-ki (me-ABL), amā-ka (me-AD), tor-ki (you-ABL), tor-ka (you-AD), amin-ka (us-AD), tmin-ka (you.PL.-AD). What is striking is that only the $2^{\text {nd }}$ person singular form $t \bar{o}$ shows allomorphic variation: tor-. More data is needed to see whether this is also possible with the $3^{\text {rd }}$ person pronouns. ${ }^{20}$ The use of free pronouns augmented with Layer II markers was recorded after the prepositions qabl "before" (< Arabic qabl) and $v \bar{e}$ "without" (< Kurdish bê): qabəl tor-ki "before you", ve $m \bar{a}-k i$ "without me". It appears also marginally in possessive clauses: tor-ka ašti di trombîlã "you have two cars" (you-AD there.is two car), amā-kā = ̌̌i āšti guštary-ā sōwon "I also have a golden ring" (me-AD=also there.is ring-INDEF gold).

\subsection{Bound pronouns}

The bound pronouns attach to nouns, verbs and a series of preposition-like morphemes.

\begin{tabular}{|l|l|l|}
\hline & Singular & Plural \\
\hline 1 & $-m$ & $-m \bar{a}(n)$ \\
\hline 2 & $-r$ & $-r \bar{a}(n)$ \\
\hline 3 & $-S$ & $-S \bar{a}(n)$ \\
\hline
\end{tabular}

Table 4: Bound Pronouns

When suffixed to singular nouns, the extension $-\bar{o}$ - is inserted between the root and the pronoun:

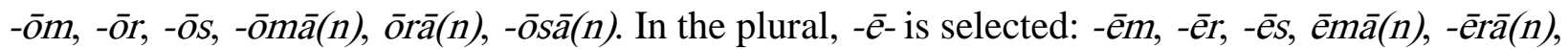
$-\bar{e} \bar{s}(n)$. Consider the following examples:

$$
\begin{aligned}
& h \bar{a} \quad \text { kəry- } \bar{o}-m \bar{a} n=e \\
& \text { DEM house-SG-1PL=COP } \\
& \text { "This is our house" }
\end{aligned}
$$

\footnotetext{
${ }^{20} \mathrm{At}$ one point, one of the informants uttered oróka, which may well turn out to be the demonstrative orron augmented with Layer I oblique case -ə- and Layer II adessive marker -ka: or-ó-ka "he has, at him". This, however, needs explicit elicitation to be confirmed. Such an interpretation was also suggested by data elicited from a Domari speaker from Sarāqib in northern Syria. Although his dialect was different from Aleppo Domari, one may expect these features to be shared by the two varieties. In Sarāqib, singular accusative forms are $\bar{e} r$-əs (proximate), $\bar{o} r$-əS (distal). Singular oblique forms are $\bar{e} r-ə$ - (proximate) and $\bar{o} r-\curvearrowright-$ (distal). The plural form is shared for both oblique and accusative: $\bar{o} r$-ən-. This is totally predictable in the light of the Layer I case system of Aleppo Domari. It is therefore very likely that Aleppo Domari exhibits the same forms. Quite intriguing in Aleppo Domari is orron for both nominative singular and oblique/accusative plural. There is however no possible overlap as they appear in different syntactic positions.
} 


$$
\begin{aligned}
& \text { qaddāh-ē-rān } \quad \bar{e} t \bar{a}=y e \\
& \text { lighter-PL-2PL } \quad \text { here=COP } \\
& \text { "Your lighters are here" }
\end{aligned}
$$

The consonant $/ \mathrm{n} /$ of the plural forms most often drops, unless followed by a vowel, as in (3):

$$
\begin{aligned}
& \text { qaddāh-ō-sā } \quad \bar{e} t \bar{a}=y e \\
& \text { lighter-SG-3PL here=COP } \\
& \text { "Their lighter is here" }
\end{aligned}
$$

With preposition-like morphemes, the bound pronouns are used: dī̌s-ōm "from me", vāš-ōm "with me" (also vāš-ìm), pās-ōm "at me", manğ-om "in me", (v)at-ōm "on me". It was also recorded with the Arabic preposition dūn "without": dūn-ōm "without me". The allomorph of the

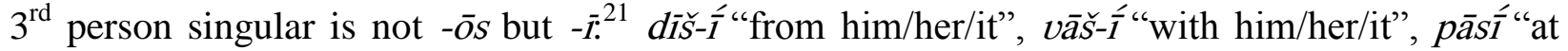

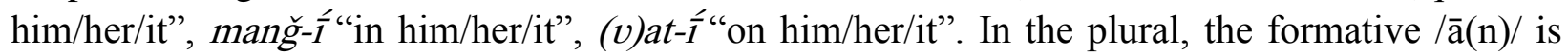
simply added: dīšyā(n) "from them", vāšyā(n) "with them", pāsyā(n) "at them", manğyā(n) "in them", (v)atyā(n) "on them". The form *ab-carries a benefactive meaning: $a b-\bar{o} m$ "for me". Contrary to what may be expected, the suffixation of the $3^{\text {rd }}$ singular pronoun gives $a b-\bar{o} S$ "for

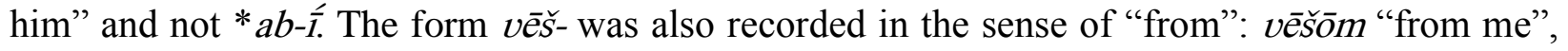
$v \bar{e} s \overline{i r}$ "from you", $v \bar{e} \bar{S}_{\overline{1}}$ "from him". These preposition-like morphemes are never used without bound pronouns so they are never used to modify a noun phrase, as case marking is the only possible strategy for that purpose. According to this, one way to look at things is to consider these preposition-like morphemes augmented with bound pronouns as allomorphs of free pronouns marked for case.

It is however still unclear what the exact difference may be between $m \bar{a}-k i$ (me-ABL) and dīšōm both meaning "from me" or tor-ka (you-AD) and pāsōr both meaning "at you". As suggested by the recorded tokens, it may well be that the marking of the pronouns by Layer II markers is restricted to marked contexts such as focalisation or topicalisation. Forms that have not been recorded so far are the pronouns marked for the versative case.

The bound pronouns are also used as object pronouns when suffixed to a verb: nerrōs-əm "he took me" (take.PFV.3SG-1SG), 'āwin karm-ər "(that) I help you" (help.SUBJ.1SG-2SG), tōm-əs "I gave him" (give.PFV.1SG-3SG), ōrin hass karond-əmān-e "they love us" (them love.IMPFV.3PL-1PL-CM), kā pdēm-ərā "I want to give you" (FUT give.SUBJ.1SG-2PL-), lakordōm-sā "I saw them" (see.PFV.1SG-3PL).

\subsection{Reciprocal}

Aleppo Domari uses the numeral $y \bar{e} k$ "one" as reciprocal augmented with the plural suffix $-\bar{e}-$ followed by a bound pronoun, as shown (6). An interesting form that was recorded involves the

\footnotetext{
${ }^{21}$ It is most likely that this was originally $-\bar{i} S$, in which /s/ dropped. This is also further evidenced by Macalister's material (1914) in which one can read forms like wăšiss "with him", ǔnkís "in it", mnēšis "from it". One finds also wāšǐš "with him" in Matras' material (Matras 2000).
} 
numeral $y \bar{e} k$ followed by the plural form of the oblique marker and the comitative: $y \bar{e} k$-ən-sa "together" (one-OBL.PL-COM). This obviously parallels the Arabic phrase ma' ba' $d$ "together" ("with each other)".

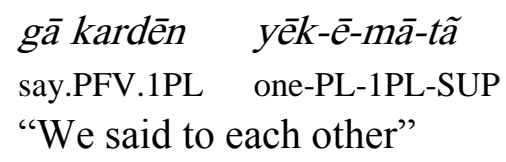

\subsection{Reflexive}

Aleppo Domari makes use of the inherited root $p \bar{a}$ - in reflexive constructions. This is very similar to what is found in Romani whose reflexive pronoun is cognate with Domari $p \bar{a}-(<$ Old Indo-Aryan àtmán "breath, soul" and Middle Indo-Aryan appā "self"). Since reflexive constructions typically involve coreference between the subject and another argument, the reflexive morpheme need not to be overtly marked with a pronoun indexing the subject, as shown in (7a) and (7b). However, this is not a rule, and the reflexive may be augmented with a bound pronoun cross-referencing the subject, as in (7c). Note that in (7b), the phrase can gafle is borrowed wholesale from Arabic. Also noteworthy is the epenthetic approximant $/ v /$ inserted between the reflexive $p \bar{a}$ - and vowel-initial bound pronoun - $\bar{s}$ to avoid hiatus: $p \bar{a} v \bar{e} s$ "themselves". The reflexive $p \bar{a}$ - was also recorded in collocation with the benefactive relational noun kērã. It surfaces most often as $p \bar{e} k \bar{e} r \tilde{a}$ "for one's self", most probably pā-ē kērã (REFLOBL for).
a. ammat sã fikr nə-karənde $\dot{g} \bar{e} r \quad p \bar{a}-n ə-m \tilde{a}$ people all thought NEG-do.IMPFV.3PL except REFL-OBL.PL-IN "All the people only think about themselves"

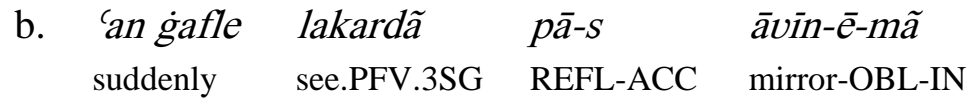 "Suddenly he saw himself in the mirror"
c. bū moṣrī (h)rōs-sa pāv-ēs dakardēnd much money become.PFV.3SG-3PL REFL-3PL see.PFV.3PL "They became rich (and) started to show off

\subsection{Demonstratives}

The set of demonstratives in Aleppo Domari seems to have been somewhat restructured when compared to what is found in Palestinian Domari (Matras 1999: 27). No gender distinction was recorded. Compare for that matter hā ğvor "this woman" and hā čăgã "this boy". In both cases, the demonstrative is invariably hā. This sharply contrasts with Palestinian Domari for which Matras gives a rather symmetrical paradigm in which nominative/oblique and masculine/feminine/plural are distinguished. In noun modifying function, the following forms 
were recorded: $h \bar{a}, \bar{e}$ and $\bar{o}$. The contrast between distal $\bar{o}$ and proximal $h \bar{a}$ is exemplified in (8). The form $\bar{e}$ is used when the modified noun is marked for accusative (9a), or oblique case and a Layer II marker (9b).

$$
\begin{array}{lllll}
h \bar{a} & \text { kori } & \bar{o} & \text { kəri } & d \bar{u} r-t a r=e \\
\text { this } & \text { house } & \text { that } & \text { house } & \text { far-more=COP }
\end{array}
$$

"This house is further away than that house"
a. no-mangǐštome
snom
$\bar{e}$
$\check{g} b-\partial S$
NEG-want.PROG.1SG
hear.SUBJ.1SG
this.OBL story-ACC
"I don't want to hear that story"
b. n-sākome
čārom
$\bar{e}$
pānd-ə-tã
NEG-can.IMPFV.1SG
drive.SUBJ.1SG
this.OBL path-OBL-SUP
"I can't drive on that road"

When used anaphorically, the following forms were recorded in the singular: hāa, hān, hanā, hanū, hnū, ōron, hanōron. In the plural: ērīn, hanērīn, ōrīn, hanōrīn. There are two possibilities to account for the emergence of the Aleppo Domari forms $\bar{e}$ and $\bar{o}$. The first one is the elision of $/ \mathrm{h} /$ in ehe and uhu. This scenario presupposes that the forms found in Palestinian Domari are the original ones. The second option is that $\bar{e}$ and $\bar{o}$ arose from the erosion of the anaphoric forms $\bar{e} r$ and $\bar{o} r$-when used in noun modifying function. More data is necessary to provide an exhaustive analysis of the system of demonstratives used in Aleppo Domari, more particularly plural forms.

\subsection{Interrogatives}

All the interrogatives recorded in Aleppo Domari are inherited: $k \bar{o}$ "who", kay "what", kačā "when", kāt katt "how", ksē "why", kā kêta "where", kēva "where to", kəzzēta "where from", $k \bar{a} k i \sim k a k k i$ "which, what". All these interrogatives are pro-forms. There does not seem to be any difference in meaning between $k \bar{a}$ and $k \bar{e} t a$ "where". However, they do exhibit syntactic dissimilarities. When the morpheme $k \bar{a}$ is used, no copula emerges: $k \bar{a}$ čri ? "where is the knife?" (where knife), kā qaddāh-ōr "where is your lighter?" (where lighter-2SG); the use of the copula or a verb is compulsory with kêta: kêtā=ye kəry-ōs "where is your house?" (where=COP house-3SG). The morpheme $k \bar{a} k i \sim k a k k i$ can also function as an interrogative determiner: kakki qāyš-əs hass kare "what food do you like?" (what food-ACC like.IMPFV.2SG). Interestingly, the object in this last example is marked for accusative case, usually triggered when the object is definite. Aleppo Domari distinguishes between kti "how many" and karda "how much". The former is an interrogative determiner (10a) while the latter is

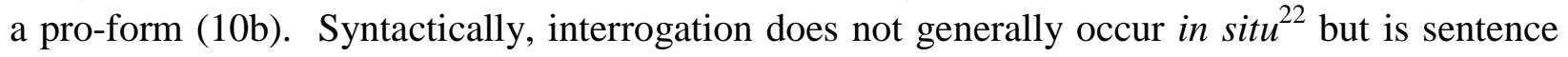
initial: kay tōs-ər" "what did he give you?" (what give.PFV.3SG-2SG)

\footnotetext{
${ }^{22}$ That is the syntactic slot of the constituent affected by interrogation.
} 

a. $\quad k t \bar{\imath}$ trombill(ã)
ašti pāsī
how.many car there.is AD.3SG

"How many cars does he have?"

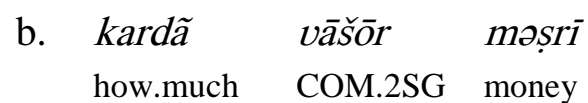

"How much money do you have?"

\subsection{Numerals}

The following numerals were recorded: yēka yōka "one" (short form yê), dədī "two" ( $d \bar{i}$ when modifying a noun: $d \bar{i}$ vars "two years"), tron "three", štàr "four", panğ "five", šěs "six", hawt ḥaft "seven", hašst "eight", na "nine", dazz "ten", dazz yēk "eleven", dazz dī "twelve", dazz tron "thirteen", dašštā "fourteen" (< dazz štâr), dazz panğ "fifteen", dazz hawt "seventeen", dazz hašt "eighteen", dazz na "nineteen", visst "twenty", vist yēka "twenty-one", vist dodì "twenty-two", vīs tron "twenty-three", vī štār "twenty-four", sì "thirty", čəl "fourty", pēnğã "fifty", tron vìst "sixty", tron vīst dazz "seventy", tron visst visst štâr visst "eighty", șadd illa dazz "ninety", șadd "hundred", hazār "thousand". Aleppo Domari draws on Kurdish for "six", "seven" and "eight" (possibly "nine" as well). ${ }^{23}$ Tens until fifty are also borrowed from Kurdish, as well "hundred" and "thousand". Above "fifty", "twenty" is repeated, to which "ten" may be added. An exception is șadd illa dazz involving Kurdish șadd "hundred", Arabic illa "except" and Indic dazz "ten". The form * štàr vist dazz to express "ninety" was not attested but cannot be ruled out. An interesting feature is the reduplication in "two" when the numeral is uttered in isolation: $d \partial d \overline{\text {. }}$ This may also have been modelled on Kurdish where $d u d u$ (also dido) is used in isolation and $d u$ when it modifies a noun: $d u$ kes "two persons". The numerals may be augmented with the plural

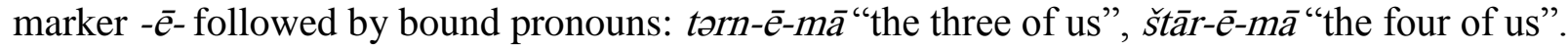

\subsection{Adverbs}

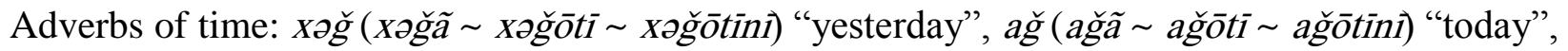
şəbã "tomorrow", īsəm hanīsəm "now", zammēšs"long ago".

Adverbs of place: èta "here", òta "there".

Other adverbs: $b \bar{u}$ "much", $t \bar{i} k \bar{a}^{24}$ "a little", tīkā tīkāaslowly", xalyā "quickly", hazz(i) "still”.

Aleppo Domari draws on Arabic for other adverbial phrases such as 'an gafle "suddenly" (also gafl-e- $k i)$, fağ’atan, taqrïban "almost", tab`an "of course". An interesting case of pattern replication appears in the phrase nēzk-ə-tã "soon" (close-OBL-SUP) which obviously parallels

\footnotetext{
${ }^{23}$ There is most probably an underlying final / $\mathrm{h} /$ in na "nine" that does not surface anymore in Aleppo Domari. This is suggested by data from Beirut Domari in which nahēs was recorded.

${ }^{24}$ The last vowel $/ \bar{a} /$ is the short allomorph of the indefinite marker $-\bar{a} k$. This is apparent when the copula attaches to the right: $v \bar{a} l-\bar{e} s t \bar{k} k-\bar{a} k=e$ "he has little hair" (hair-3PL little-INDEF=COP).
} 
Arabic 'an qarīb (from close), but employs the Kurdish derived adjective nēzok "close" augmented with the inherited superessive marker -tã.

\subsection{Nouns}

Not many derivational affixes were found in Aleppo Domari. The most common is the indefinite marker -āk: kām-āk "a thing". This suffix, also found in Palestinian Domari, is common in Kurdish and some Indic languages (Matras 1999:15). Unlike Palestinian Domari, the formative

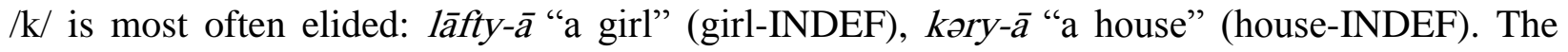
consonant $/ \mathrm{k} /$ is however compulsory when additional material is attached to the right: $k ə r y-\bar{a} k$ - - $m \tilde{a}$ "in a house" (house-INDEF-OBL-IN), vəddy-āk=e "(it's) an old woman" (old.woman$\mathrm{INDEF}=\mathrm{COP}$ ). Interestingly, the suffix can co-occur with a short form of the numeral yēka

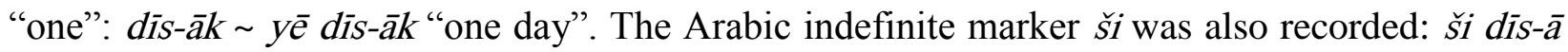
"one day". Gender as an inflectional category has been lost in Aleppo Domari. It only survives residually in derivational morphology: kağğã "man” vs. kağğ̄i “woman”, drōngã "old man” vs. drōngi "old woman". The feminine ending $-\bar{i}$ also appears in vəddi "old woman", but the masculine *vəddã was not attested (kəčmārã "old man" is used instead). Other derivational suffixes found in the corpus are the nominalisers -ǐšs qāyī̌s "food", mangīš "request", rawī̌s "walk", marīš "burial", biñāvīšs "fear", vāyīš "hit"; and -vāy. dorgvāy "tallness", mištvāy "disease", čăgivāy "childhood". More data are needed to assess the productivity of these suffixes.

\subsection{Layers of case marking}

The concept of layers of case marking in Indo-Aryan languages was introduced by Masica (1991) and subsequently applied to Romani and Domari by Matras (1999 \& 2002). Case marking in Domari is quite similar to what can be found in other Indic languages. Three layers are usually recognised. Layer I is a marker of non-nominative, traditionally labelled oblique, that attaches directly to the base. Layer II morphemes attach to the base augmented by the Layer I marker. Layer III markers usually consist of adpositions requiring that the head noun is augmented with a Layer II marker.

\subsection{Layer I}

The morphemes that attach directly to the lexical base in Aleppo Domari are -əS, $-\partial$, and -ən. The extension $-\partial S$ is an accusative marker, as evidenced by (11a). However, object marking is not systematic, as shown in (11b). Such a split is common in languages that exhibit differential object marking. This usually happens when the object is high on the topicality scale. Crosslinguistically, differential marking usually reflects a distinction between animate/inanimate or definite/indefinite (Lazard 1998:219). In Domari, definiteness is the main factor that governs object marking (Matras 1999:15). Aleppo Domari is not innovative in that matter and exhibits the same pattern, as evidenced when one of the informants, who was recalling what he had done in the morning, was telling us that he had asked his wife to prepare coffee for him. As a new participant introduced into discourse, the word for coffee remains unmarked (11b). In (11c) the 
entity "coffee" is now identifiable as it has just been introduced, and therefore marked for accusative. This pattern of object marking is quite common in the languages of the area (Turkish, Persian, Levantine Arabic) and may well turn out to be an areal feature.
a. taqrīban sāca dazz lvā kardōm talfizyōn-əs about hour ten open.PFV.1SG television-ACC
"At about 10, I turned on the television"
b. gārdōm ğovr-ōm-tã abōm karor qaḥwa say.PFV.1SG wife-1SG-SUP for.1SG make.SUBJ.3SG coffee "I said to my wife to make some coffee for me"
c. kardã abōm qaḥw-ēs tordōs-əs make.PFV.3SF for.1SG coffee-ACC put.PFV.3SG-3SG
"She made the coffee for me and put it (down)"

The main function of the marker -ə in Aleppo Domari is to be the morphological support for the suffixation of Layer II case markers. In (12a), the Layer II ablative marker $-k i$ cannot attach directly to the base and the oblique -ə needs to appear between the noun and the Layer II marker. As shown in (12b), the oblique marker also appears consistently after a close set of relational nouns that mainly express spatial relations (see below for a discussion of relational nouns). This is a remnant of what must have been the main function of the oblique marker in Aleppo Domari, that is to mark the modifier in genitive constructions (see below for a discussion of genitive constructions). While in Aleppo Domari, the genitive function of the oblique marker is mainly apparent with relational nouns, it is better preserved in other varieties (examples are from the dialect of Beirut): mons-a krī "the house of the man" (man-OBL house), dōm-a gāl "the language of the Dōm" (Dōm-OBL language), 'arīs-a bāb "the father of the groom" (groom-OBL father), 'arūs-a 'ābin "the clothes of the bride" (bride-OBL clothes).
a. parme
kəry-ə-ki
return.IMPFV.1SG
house-OBL-ABL
"I go back home"

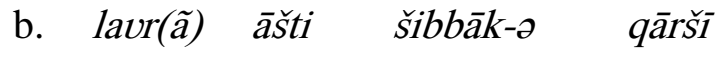
tree there.is window-OBL in.front.of
"There is a tree in front of the window"

The marker -on fulfils two functions. It marks plural accusative, as shown in (13), and serves as a plural oblique marker that allows the suffixation of Layer II markers as in (14). As noted above, accusative marking occurs only when the encoded participant is referential or identifiable. 


$\begin{array}{lll}\text { amā } & \text { hass kamme } & \text { čà } \dot{g}-\text {-on } \\ \text { I } & \text { like.IMPFV.1SG } & \text { child-ACC.PL }\end{array}$

"I like kids"

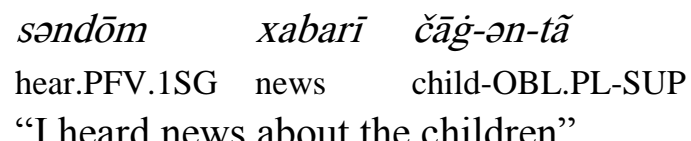

In items borrowed from Arabic ending in -e (feminine marker), the oblique case is usually realised $-\bar{e}$ - and accusative case $-\bar{e} s$, as in (15) and (16). These allomorphs were also recorded twice with inherited items: agōr-ēs (horse-ACC) (< Indo-Aryan ghōta) and $z$-lavr- $\bar{e}-k i$ "from the tree" (from-tree-OBL-ABL) (< Indo-Aryan lakuta). In the plural, the Layer I marker is invariably -èn: agōr-ēn (horse-ACC.PL), lavr-ēn-ka "at the trees" (tree-OBL.PL-AD). The oblique plural marker was also recorded with akkī"eye": akky-ēn-ki "from the eyes".

$\begin{array}{llll}\text { amāa } & \text { faḍdil karme } & q a h v_{\text {-ēs }} & k i \bar{r} \text {-ə-tã } \\ \text { 1SG } & \text { prefer.IMPFV.1SG } & \text { coffee-ACC } & \text { milk-OBL-SUP }\end{array}$

"I prefer coffee to milk"

$\begin{array}{lll}p \bar{e} n & \text { qamīṣ-əS } & x z \bar{a} n-\bar{e}-k i \\ \text { take out.IMP } & \text { shirt-ACC } & \text { wardrobe-OBL-ABL }\end{array}$

"Take the shirt out of the wardrobe"

The Layer I case system in Aleppo Domari can be summarised this way:

\begin{tabular}{|l|l|l|}
\hline & Accusative & Oblique \\
\hline Singular & $-(\partial)_{S},-\bar{e} S$ & $-\partial,-\bar{e}$ \\
\hline Plural & $-(\partial) n,-\bar{e} n$ & $-(\partial) n,-\bar{e} n$ \\
\hline
\end{tabular}

Table 5: Layer I

Data available from other dialects suggest that this pattern is shared by all northern varieties of Domari (at least Beirut, Aleppo and Sarāqib). Palestinian Domari exhibits an older stage -also shared by Romani- that distinguishes grammatical gender: $-a$ marks feminine nouns for both accusative and oblique and - as marks masculine nouns for both accusative and oblique (Matras 1999:18). It appears from this that northern varieties of Domari innovated and restricted the old feminine $-a$ to a general oblique marker and the old masculine - $a$ s to a general accusative marker. This innovation in northern Domari is of course linked with the loss of gender as an inflectional category. What is not documented, though, is whether the loss of gender distinction was triggered by the restructuring of the Layer I system and other sub-systems such as the demonstratives, or the other way around.

\footnotetext{
${ }^{25}$ The form kamme in (13) comes from the assimilation of $/ \mathrm{r} /$ to $/ \mathrm{m} /:$ karme $\rightarrow$ kamme (this assimilation occurred only in that example). This verb is a borrowing from Kurdish hez kirin "love".
} 


\subsection{Layer II}

The Layer II morphemes primarily mark spatial relations (except for the comitative). Only morphemes that co-occur with Layer I belong to the inventory. According to this criterion, the following markers were identified:

\begin{tabular}{|l|l|l|}
\hline Label & Form & Primary meaning \\
\hline inessive & $-m \tilde{a}$ & "in" \\
\hline superessive & $-t \tilde{a}$ & "on" \\
\hline adessive & $-k a$ & "at" \\
\hline ablative & $-k i$ & "from" \\
\hline versative & $-v a$ & "towards" \\
\hline comitative & $-S a$ & "with" \\
\hline
\end{tabular}

Table 6: Layer II

The primary meaning of the inessive marker $-m \tilde{a}$ is to indicate location, with or without confinement: vyār-o-mã "in town, in the market", libnān-o-mã "in Lebanon". It also extends to temporal expressions: slậl-ə-mã "in the winter", $\bar{e}$ dīs-ən-mã "in these days". The marker -mã is also used with an instrumental meaning čory-ə-mã "with a knife", $\check{s} \bar{a} k \bar{u} \bar{s}$-ə-mã "with a hammer". This is obviously the result of alignment with Levantine Arabic in which the preposition $b$ - is commonly used for both locative and instrumental. The formative /ã/ is often elided, leaving $-m$ alone to mark location: kəryəm "in the house", pānyəm "in the water".

The morpheme -tã is used to indicate the top or the surface of the marked noun: $s r-\bar{o} s$-tã "on his head", pānd-ə-tã “on the way". It was also recorded with a simple locative meaning in marǐšo-tã "at the burial". It is also commonly used for time reference: $\bar{a} r \bar{a} t$-ən-tã "in the night", $s b$-əntã "in the morning", zamān-ən-tã "in the past, back in the old days". Another common meaning cover by -tã is "about": pčārdōs-om pāpīr-ə-tã "he asked me about (his) grand-father" (ask.PFV.3SG-OBJ.1SG grand-father-OBL-SUP). One instance of instrumental meaning was found in the following example: qēğăr-əs dōvištōme xašt-ōm-tã "I'm washing the clothes with my hands" (garment-ACC wash.PROG.1SG hand-1SG-SUP). The recipient of the verb ga kar "say" is also marked with superessive -tã, as apparent from (17):

\begin{tabular}{|c|c|c|c|c|}
\hline gārdōmm ${ }^{26}$ & $q r-\bar{o} m-t \tilde{a}$ & ǧār & ǧib karor & vāšōor \\
\hline say.PFV.1SG & small son-1SG-SUP & go.SUBJ.3SG & speak.SUBJ.3SG & COM.1SG \\
\hline
\end{tabular}

\footnotetext{
${ }^{26}$ This verb also appears in Macalister's (1914) material but in a different form: gál-kerdi barúskă "she said to her brother". The form $g \bar{a} l \mathrm{k}$-was also maintained in Beirut but means "speak": gāl əkrōm "I spoke". The recipient-like argument is marked in Palestinian Domari with the adessive marker -ka (kă in Macalister's transcription), whereas Aleppo and Beirut Domari favour the superessive marker -tã.
} 
This also extends to verbs borrowed from Arabic whose objects are introduced by the preposition 'ala "on": 'arraf(h)rōm kətčmār-āk-ə-tã "I met an old man" (meet.PFV.3SG old.man-INDEFOBL-SUP). The verbal form 'arraf(h)rōm is analysable as 'arraf, from Arabic t'arraf"to meet" and the Domari verbal root $h$ - "to become" which is used as a light verb and serves to integrate foreign elements into Domari lexicon. The Arabic verb t'arraf introduces its complement with the preposition 'ala "on". Accordingly, when transferred into Domari, the complement of the complex verb 'arraf $h$ - will be marked with the superessive marker -tã, whose primary meaning corresponds to Arabic 'ala. This is a clear example of pattern and matter replications being active at the same time. ${ }^{27}$ Argument marking patterns without lexical borrowing are also prone to replication: nāvištōme tron nārn-ə-tã "I'm looking for three men" (< Arabic dawwar 'ala "to look for something"). Noteworthy is the fact that no dative or allative functions were recorded, hence the impossibility to label the marker -tã "dative", as in Palestinian Domari. In allegro speech, only - $t$ may surface: $x \bar{a} t r$-ə- $t$ "on (his) mind" (mind-OBL-SUP).

The case marker - $k a$ commonly translates the Arabic preposition 'ind "at, by" (cf. French "chez"). It has a rather loose locative meaning and refers more typically to the place of residence or work: doktōr-ə-ka "at the doctor's" (doctor-OBL-AD), garōm ē kağğ-ə-ka "I went to that man's place” (go.PFV.1SG DEM.OBL man-OBL-AD). It appears also very often in possessive constructions. This seems to be contact-induced and parallels possessive constructions in Arabic which also make use of the preposition 'ind. Contrast (18a) and (18b), where only constituent order differs (see below for more on possessive clauses):
a. tmin-ka (a)šti trombīlã
(Domari)
2PL-AD there.is car
b. fi ‘and-kun sayyāra
there.is AD-2PL car
"Do you have a car?"
(Arabic)

The comitative marker -sa has a straightforward meaning and denotes companionship: ğib kardōm māyn-āk-ə-sa "I spoke with a woman" (speak.PFV.1.SG. woman-INDEF-OBL-COM). No instances of instrumental meaning were recorded. It should be added that companionship may also be expressed periphrastically through the coordination of two NP's by way of the conjunction la "and": bāzār-o dīs ğāme ğām '-ə-ki mā la dī bēn-ē-m "On Friday, I go to the mosque with my two sisters (me and my two sisters)" (Friday-OBL day go.IMPFV.1SG mosqueOBL-ABL me and two sister-PL-1SG).

The versative marker - va is not very frequent in the corpus and, to the best of my knowledge, does not appear in any other source about Domari. ${ }^{28}$ It occurs most frequently in the interrogative

\footnotetext{
${ }^{27}$ Matter and pattern replication are taken from Matras (2009a) who provides an interesting model of language contact. Matter replication refers to the borrowing of linguistic material, or in Heine \& Kuteva's terminology "the transfer of linguistic form-meaning units" (Heine \& Kuteva 2005). Pattern replication refers to the transfer of underlying morphosyntactical structures and relations (see in particular Matras 2009a:234-274).

${ }^{28}$ It was also recorded in the dialect of Beirut and in the dialect of Sarāqib so it appears to be shared by all northern varieties.
} 
kēva "where to?" (kēva garã "where did (s)he go?"). It was also recorded in temporal expressions: tammūz-ə-va "from july (onwards)", and the locational adverb fatnāwa "above" (together with fatnāka, marked here with adessive -ka). When it marks a noun denoting a location, its meaning is closer to "towards, in the direction of" rather than a bare allative encoding destination. For this purpose, the noun is zero-marked or marked with $-k i$ (see below). If the noun marked with - $v a$ refers to time, its meaning is "for, since". ${ }^{29}$ The marker - $v a$ is most likely to have been borrowed from Kurdish (Kurmandji va, Sorani (a)wa), in which it appears as a postposition that can combine with other prepositions to express a variety of spatial meanings. ${ }^{30}$

The marker $-k i$ is highly multifunctional. The term "ablative", which appears in both Macalister (1914) and Matras (1999), has been maintained here because it seems that its primary function is to encode source, as suggested by (19).

$\begin{array}{lll}b \bar{e} n-\bar{o} S & \text { parde } & \text { vyār-ə-ki } \\ \text { sister-3SG } & \text { return.PRF.3SG } & \text { market-OBL-ABL }\end{array}$

"His sister has come back from the market"

However, $-k i$ was also recorded to encode destination, to mark the recipient-like argument in ditransitive constructions, as a prepositional case and also in genitive constructions (see below). The allative function is probably the most surprising, especially if it is acknowledged that $-k i$ is originally an ablative marker. In (20), its presence or absence was equally accepted:

$\begin{array}{llll}\text { (20) hatta } & \text { rāšton } & \text { vyār-ə-ki } & \text { vyār } \\ \text { in order to } & \text { arrive.SUBJ.1PL } & \text { town-OBL-ABL } & \text { town }\end{array}$

"In order to get downtown"

This suggests that $-k i$ does not encode origin or goal, but simply motion. The ablative or allative interpretations are given by the semantics of the verb. This kind of syncretism is said to be particularly rare cross-linguistically (Creissels 2009: 615). ${ }^{31}$ A possible explanation for this is that Aleppo Domari has acquired from Western Iranian and Arabic a set of prepositions, amongst which one finds $z$ - "from", leading to a morphological hypercharacterisation on the head noun which is marked twice for ablative, as evidenced by these examples: $z$-mistašfă- $k i$ "from hospital" (from-hospital-ABL), $z-d \bar{a} w a t-\partial-k i$ "from the wedding" (from-wedding-OBL-ABL). It is very likely that the morpheme $-k i$ in these examples does not encode source any longer but simply became a prepositional case. The source encoding function would thus solely be carried by the preposition $z$-. The marker $-k i$ used as a prepositional case was also recorded in the

\footnotetext{
${ }^{29} \mathrm{An}$ example recorded in the dialect of Beirut is šêš wars-a-wa wēsr(e) êta "he's been living here for six years" (six years-OBL-VERS stay.PFV.3SG here).

${ }^{30}$ One example in Suleymaniyyah (Iraq) Kurdish in which awa combines with the preposition la with an ablative meaning: la karkūk-awa "from Kirkuk" (McCarus 2009:601).

${ }^{31}$ The term "motative" is used the capture the semantics of this case in Ardeşen Laz (Kutscher \& Genç 2006: 251). It may be an alternative to the term "ablative" in Aleppo Domari. Saying that the ablative case can be used to encode destination may indeed sound contradictory.
} 
following (see below for a discussion of prepositions, the so-called Layer III markers): qabol $\bar{e}$ $x a t r-\bar{e}-k i$ "before that time, previously" (before this.OBL time-OBL-ABL). Another common function of $-k i$ is to mark the recipient-like argument in ditransitive constructions, as in (21):

tōm dād-ōm-ki bkēZ guštary- $\bar{a}$

give.PFV.1.SG. mother-1SG-ABL nice ring-INDEF

"I gave my mother a nice ring"

As shown above, argument marking patterns of certain verbs are also transferred from Arabic into Domari. The Arabic verb $x \bar{a} f$ "he was afraid" introduces its complement with the preposition min "from": bitxāf min in-nār "she is afraid of fire" (fear.IMPFV.3.SG.f. from DET-fire). This in Domari becomes byāre $\bar{a} g$-ə-ki (fear.IMPFV.3SG fire-OBL-ABL). It is very likely that the marking of the complement of Domari $b \bar{i}$ - "fear" with $-k i$ is a case of pattern replication.

\subsection{Layer III}

Layer III markers are represented by a set of prepositions borrowed from Iranian languages and

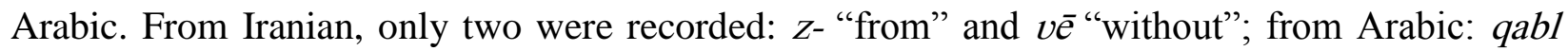
"before", $b a^{\prime} d$ "after", $b$ - be "with (instrument)" and badāl"instead". Traces of $z$ - were neither found in Kurmanji nor in Sorani. It is however common in Persian (az "from"). Accordingly, Domari $z$ - may have been borrowed from a variety of Persian. The preposition $z$ - is not a recent borrowing as it is already mentioned in Newbold (1856:312, see above). It mostly appears with the Layer II ablative marker $-k i$ which acts here as a prepositional case marker (see above): $z \boldsymbol{~}$ tâv-o-ki "from (this) place" (from-place-OBL-ABL), $z$-lavr-e- $k i$ "from the tree". Instances of $z$ alone were also found: zo-vyār "from the market", z-ēta "from here", z-ašrafiyye "from Ašrafiyye (a neighbourhood in Aleppo)". The absence of -ki may be lexically conditioned and the use of $z$-alone restricted to certain items, mostly locational expressions. The preposition $z$ may also co-occur with the adessive marker -ka. It commonly translates the combination of Arabic min "from" and 'ind "at" and faithfully combines the semantic load of both Layer III ablative $z$ - and Layer II locative -ka: $z-b \bar{e} n-\bar{o} r-k a$ "from your sisters' place" (from-sister-2SGAD), $z$-bēly-ōm-ka "from my friend's place" (from-friend-1SG-AD).

The preposition $b$ - "with (instrumental)" was also borrowed into Kurdish from Arabic, so it may well be the case that $b$ - was initially borrowed from Kurdish and not from Arabic. Its use appears quite marginal in Aleppo Domari, most probably because several strategies compete in Domari to express instrumental, the most common being the inessive marker -mã. The modified noun was recorded once with ablative $-k i$ : $b-\bar{e}$ xēzarān-ə-ki "with that stick" (with-this.OBL stick-OBL-ABL); and once without Layer II marker: bi črī "with a knife".

The preposition $v \bar{e}$ is probably a loan from Kurdish. Strangely enough, in Kurdish (and Persian), this preposition is realised with a $/ \mathrm{b} /$. One possible explanation is that $/ \mathrm{b} /$ was turned into a $/ v /$ in Domari to avoid homophony with the preposition $b$-. Ablative marker $-k i$ after $v \bar{e}$ was recorded only after free pronouns: $v \bar{e} m \bar{a}-k i$ "without me" and $v \bar{e}$ tor-ki "without you". These can be replaced by Arabic dūn "without", augmented by bound pronouns: dūn-ōm "without me". The preposition $v \bar{e}$ also appeared with a zero-marked noun: $v \bar{e}$ daff "without 
wood". Arabic qabl "before" is commonly used. Instances of use with ablative -ki were recorded with nouns and free pronouns: qabəl tor-ki "before you", qabəl $\bar{e} x a t r-\bar{e}-k i$ "before that". Another common meaning of qabl in Arabic is "ago": qabəl sintēn "two years ago". This was rendered in Domari qabəl di vārs, without the head-noun being marked with -ki. The Arabic preposition $b a^{\prime} d$ "after" was also borrowed into Domari. In all recorded tokens, the head-noun is never modified by -ki: ba'd štār dīs "four days later". No instances of modified pronouns could be recorded. It seems there are alternative ways in Domari to express the same meaning. One of the informants judged equivalent these two sequences: $b a^{\prime} d t i \bar{k} \bar{a} \sim t \bar{k} \bar{a} d o r m i$ "soon, in a moment". It is likely that $b a^{\prime} d$ is a recent borrowing and replaced a morpheme of Iranian origin. This is suggested by the way of expressing "afternoon" as shown in (23). ${ }^{32}$

$\begin{array}{lllll}k \bar{a} & \text { pāvom } & \text { pāsōr } & \text { nimro } & \text { pāštar } \\ \text { FUT come.SUBJ.1.SG. AD.2SG } & \text { midday } & \text { after } \\ \text { "I'll come to your place in the afternoon" } & \end{array}$

Another Arabic preposition that was replicated into Domari is badāl "instead": badāl siǧiq-ə-ki "instead of sujuk (Turkish sausage)". Other core Arabic prepositions such as mac"with", $f i$ "in", min "from", 'ala "on, to", la "to, for" and 'ind"at" did not make their way into Aleppo Domari.

\subsection{Syntax of the noun phrase}

In genitive constructions, the most common order is modifier-head. One possibility is to have the modifier marked for ablative case, and the head-noun augmented with a $3^{\text {rd }}$ person bound pronoun indexing the modifier. This is the favoured pattern for NP's whose syntactic position does not impose additional morphological marking: lāfč $y$-ə-ki $b \bar{a} b-\bar{o} S$ "the father of the girl" (girl-OBL-ABL father-3.SG.), bakr-ə-ki panir-ōs "lamb cheese" (lamb-OBL-ABL cheese-3SG); or more complex constructions, as evidenced in (24). Contrary to Palestinian Domari which exhibits singular agreement, the $3^{\text {rd }}$ person bound pronoun agrees in number with the modifier: $d \bar{i}$ $b \bar{e} n-\bar{e}-m-k i$ dām-əsān "the room of my two sisters" (two sister-PL-1SG-ABL room-3PL). The marker $-k i$ on the modifier drops when other morphological material is suffixed. Under the same conditions, the bound pronoun indexing the modifier on the head also drops: ahl-om korí "the house of my family", mām-ōm qor "my cousin". This is also exemplified in (25). Another reason to avoid ablative marking on the modifier in (25) is that the head-noun is already marked with $k i$, which obviously refers to motion (see "motative" above). This constituent order in genitive constructions seems to be quite stable and no instances of head-modifier order were recorded, suggesting that convergence with Arabic did not take place in genitive constructions. This

\footnotetext{
${ }^{32}$ The morpheme pāštar was not recorded in other contexts and may be linked to Iranian pošt "back" (Kurmanji pişt). The word nimro is most probably a borrowing from Kurdish (Kurmanji nîvro). What is more puzzling is the consonant $/ \mathrm{m} /$ and not $/ \mathrm{v} /$ (or for that matter $/ \mathrm{v} /$ ), showing that nimro must have been borrowed from dialectal Kurdish or another variety of Iranian (c.f. Persian nīm "half"). The morpheme nìm also appears in nīm ārāt "midnight" and nim sā́a "half an hour". In the dialect of Sarāib, ba ‘ad nimro (after noon) was recorded, whereas the dialect of Beirut simply borrowed the Arabic phrase ba'd oḍ-dohor (after DEF-noon).
} 
sharply contrasts with what is recorded in contemporary Palestinian Domari, in which the order is constantly head-modifier, displaying total convergence with Arabic (Matras 1999:22).

$\begin{array}{lllll}\bar{e} & \text { mons-ə-ki } & s r-\bar{o} s-t \tilde{a} & q o l & \bar{a} \tilde{s} t \bar{a} \\ \text { this.OBL } & \text { man-OBL-ABL } & \text { head-3SG-SUP } & \text { hat } & \text { there.was }\end{array}$

"There was a hat on the head of this man (this man had a hat on his head)"

$\begin{array}{llll}\text { garōm } & \text { vāši } & \text { lāfty-ōs } & \text { dāwat-ə-ki } \\ \text { go.PFV.1SG } & \text { COM.3SG } & \text { girl-3SG } & \text { wedding-OBL-ABL }\end{array}$

I went with her/him to the wedding of her/his daughter

When the head-noun is modified by an adjective, the most common order is also modifier-head. The adjective is marked with the central vowel [ə], homophonous with the oblique marker -ə: trōt-ə bār-ōm "my little brother" (little-OBL brother-1SG), trōt-ə lāfč̀- $\bar{a}$ "a little girl" (littleOBL girl-INDEF). This sharply contrasts with Palestinian Domari where the adjective agrees in gender with the noun it modifies: tilla zara "the big boy" vs. tillī lāšn "the big girl" (Matras 1999:27). The Palestinian pattern is of course most likely to be the original one and here again Aleppo Domari underwent restructuring as a result of the neutralisation of gender distinction. As noted above, short vowels show a strong tendency toward centralisation and it may well be that this vowel was reinterpreted as the oblique marker, further extending its function to mark another kind of head-modifier construction. It should be added however, that certain adjectives were never recorded with the oblique marker: $b k \bar{e} z$ qāyǐs "good food". It is also elided in the presence of homorganic consonants: trōt čăgã "little boy", drōng kəry-āk-ə-mã "in a big house" (big house-INDEF-OBL-IN).

The linear arrangement described above is not systematic and the order head-modifier was also recorded: trombīlã navvã "a new car", lāfty-ā muḥtaším "a well-behaved girl” (girl-INDEF well-behaved). There are hints that alternation of word order within the NP may be partially sensitive to definiteness. While the order modifier-head is clearly unmarked as far as definiteness is concerned, the order head modifier always refers to indefinite entities.

As far as comparative constructions are concerned, Aleppo Domari shows Kurdish, Turkish and Arabic influence. From Kurdish, it borrowed the widespread Iranian marker -tar to derive comparatives. Since it carries stress, it behaves as a real affix and forms a new phonological word: drōngã "big" vs. drōng-tár "bigger", dūr "far" vs. dūr-tár "further", zangīl "rich" vs. zangīl-tár "richer". It was once recorded -tá: xalyā-tár xalyā-tá "faster" (< xalyā "fast"). Suprinsingly, when the standard is a full NP, it remains unmarked, as illustrated in (26a). This pattern is found neither in Kurdish nor in Arabic in which ablative marking prevails (by way of a preposition: $j i$ "from" in Kurmandji, min "from" in Arabic). However, when it appears as a pronoun, it is marked for ablative, as in (26b).

$$
\begin{aligned}
& \text { a. } \begin{array}{l}
\text { kəry-ōs } \\
\text { house-3SG }
\end{array} \quad \begin{array}{l}
\text { horm } \\
\text { house-1SG }
\end{array} \quad \begin{array}{l}
\text { drōng-tar=e } \\
\text { big-more=COP }
\end{array} \\
& \text { "His house is bigger than my house" }
\end{aligned}
$$




\section{b. bār-ōs vēš $\quad$ drong-tar $=e$ panğ vars \\ brother-3SG ABL.3SG big-more=COP five year \\ "His/her brother is five year older than him/her"}

The superlative may be formed using what appears to be a Turkish morpheme $\bar{a} n$ (I.P.A. [a:n]), placed before the adjective: ān drōng krri "the biggest house". It's very plausible that this morpheme is not a direct borrowing from Turkish but rather from Kurdish, whose Central Anatolian varieties frequently borrow the Turkish comparative and superlative (Haig 2007:172). Somewhat puzzling is the phonetic shape of this morpheme in Aleppo Domari which exhibits a back vowel [a], while Turkish and Kurdish exhibit a front vowel: en.

There are signs that this mixed Kurdish-Turkish system is competing with Arabic. In Arabic, comparatives of superiority are derived through non-concatenative morphology, which makes it harder to replicate than derivational affixes, this is why the derived forms are simply borrowed from Arabic: aktar "more" (< ktīr "a lot"), ahsan "better" (< hasan "good"), aqall "less" (< qalīl "little").

Two patterns were recorded for comparison of equality. One employs the morpheme qattã, placed after the standard, which makes it look like a relational noun (see below): kory-ōs drōng=e kəry-ōm qattấ"his house is as big as mine" (house-3SG big=COP house-1SG quantity). A possible origin for qattã is the Arabic preposition qadd "as, like" (itself the result of the grammaticalisation of the noun qadr "quantity"), marked with superessive -tã.The second pattern involves the nominal derivation of the adjective marked with superessive -tã: panğ dorgvāy-om- $t=e$ "(s)he is as tall as me" (3SG tallness-1SG-SUP=COP) . It seems that this structure is possible only when the nominal derivation is available in the lexicon: dorgã "tall", dorgvāy "tallness".

\subsection{Relational nouns}

As described above, Aleppo Domari shares with Palestinian Domari and more generally with New Indo-Aryan languages a nominal morphology based mainly on two layers. Layer I is the suffixation to the base of an oblique marker, often similar to the accusative marker. It was noted that in Aleppo Domari, the Layer I system was restructured to differentiate the Layer I oblique marker from the accusative. It is most likely that this restructuring is the outcome of the loss of gender as an inflectional category in Aleppo Domari. Indeed, data available from Palestinian Domari suggest that the marker -as was restricted to masculine nouns, while $-a$ was used with feminine nouns (Matras 1999: 17-18). This, in all likelihood, represents the old, conservative pattern. Since gender distinction was lost in Aleppo, -as was reassigned as a general accusative marker and $-a$ as a general oblique marker. Layer II markers attach to the right of the base, itself augmented with the oblique marker: kirr-ə-tã "on the milk" (milk-OBL-SUP). Morphologically, the Layer II markers qualify as affixes because they are very selective about the lexical category they attach to (mainly nouns). Phonologically, however, they would rather qualify as clitics because they are never stressed, as if the last segment of the phonological word was the oblique marker -ə. Accordingly, it may be more accurate to write kīr-ś=tã rather than kīr-ó-tã. Layer II markers most probably emerged from the grammaticalisation of relational nouns used in genitive 
constructions. This would also explain why Layer II markers are not stressed. Such a class of relational nouns still exists in Domari and mainly expresses spatial relations. The following items

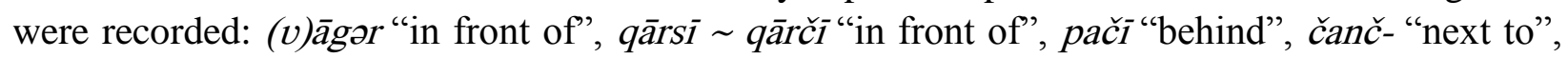
bārã "outside", manğ̃i "inside", xor- "inside, in the middle", čōrm- "around", vatūn "above", ār"between", bnã "under" and also benefactive kêrã "for". These relational nouns appear syntactically as heads of genitive constructions, although they are more like modifiers semantically. The modified noun in such constructions is always marked with the oblique marker: ğăm 'é qāaš̌ "in front of the mosque". The relation "in front of" is rendered with two

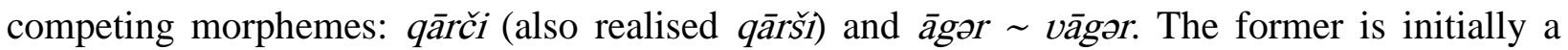
Turkish morpheme (karşI "face") borrowed into Domari probably through Kurdish, while the latter is inherited: kəry-ə qārš̄i kəry-ə vāgər "in front of the house". The consonant [v] is likely to be epenthetic. When it is not realised, the oblique marker may drop: mahall āgor "in front of the shop". The morpheme pači "behind" is also inherited: qāpy-ə pači "behind the door" (< Turkish kapı "door"), pišt-ə pačī "behind (his) back”, gağğ-āk-ə pačī "behind a man”. To express proximity, Domari makes use of the morpheme čanč-. It may be used alone: lavr-e-e $\check{c}$ canč $=e$ "(it's) next to the tree"; but it appears most often combined with the superessive marker -tã, as exemplified in (27):

lavrã kəry-ə $\quad$ čanč-ə- $t=e$
tree house-OBL next-OBL-SUP=COP
"The tree is next to the house"

The root $\check{c} \overline{o r m}$ - marked for plural combined with the superessive marker -tã is used to express the spatial relation "around": čōrm-ē-s-tã "around him" (around-PL-3SG-SUP), kəry-ə čōrm-əntã "around the house" (house around-OBL.PL-SUP). It is still unclear whether čōrm- is still a productive nominal root in Domari or only survived in this context. The inherited morpheme to express "outside" is bārã and is also postponed to the noun, as in shown (28):

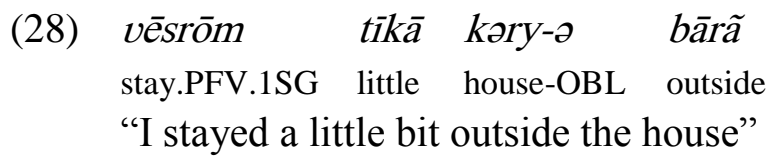

There are a couple of ways to convey inessive meaning. Most commonly this is carried out by the Layer II marker -mã. Another way is to use manğ- "in" augmented with what seems to be the $3^{\text {rd }}$ person singular bound pronoun allomorph that attaches to the close set of preposition-like morphemes: kəry-ə manğī "inside the house". Most often though, this is expressed with the morpheme xor whose primary meaning is "heart" (see below).

In Palestinian Domari, Matras (1999:20-21) identified another Layer II marker fulfilling a benefactive function: -ke. This marker originally comes from kera, still attested in Macalister's material but not in contemporary Palestinian Domari (except in amakera "for me"). The corresponding form in Aleppo Domari is kērã and also has a clear benefactive meaning. Its inclusion into the set of Layer II markers is not possible because it behaves as an independent phonological word, being normally stressed on the last syllable: ārāt-ó kêrấ "for the night". 
Moreover, kērã is never reduced to -ke in Aleppo Domari. For these reasons, kērã is best analysed as a relational noun. It is also striking that Domari has kept almost intact the form attested in Middle Indo-Aryan kāira (< Old Indo-Aryan kāryá "to be done", see Masica (1991:212)). It is also frequent for kērã to appear in collocation with xor "heart": alla xor-kērã "for God's sake", bār-ōm dāwat-ə xor-kērã "for my brother's wedding" (brother-1SG weddingOBL heart-for). It seems that the sequence xor-kêrã is undergoing lexicalisation. This is suggested by stress, carried by the last syllabe: xor-kêrấ, and also by the lack of oblique marking on xor: *xor-ə kērã. It should be noted however that xor and kērã reappear as two separate entities when bound pronouns are suffixed, as these normally attach to xor: xr-ōs kērã "for him". An alternative meaning is "because of": mištə(h)rã $x r$-ōs kērã "(s)he got sick because of him", kam-āk-ə xor-kērã $z$ ’əllã vēšom "he got angry at me because of something" (thing-INDEF-OBL because get.angry.PFV.3SG ABL.1SG). The morpheme kêrã, unlike what is reported in Palestinian Domari, was never recorded in collocation with free pronouns (only abōm kērã "for me" surfaces once in the corpus, suggesting it is marginal).

The morpheme xor "heart" is often used as a relational noun to denote confinement. It is never used alone and was recorded augmented with bound pronouns, the inessive marker -mã and the ablative marker $-k i$. The following example illustrates its use with bound pronouns: finğān-ə $x r-\bar{O} S$ "inside the cup" (cup-OBL heart-3SG). The 3SG bound pronoun obviously refers to finğān. Since plural items were not recorded in this position, it remains unknown whether 3PL $-s \bar{a}(n)$ would be used in such a case. On pure prosodic grounds, a form such as $x r-\bar{o} s$ is best viewed as a clitic because primary stress falls on the oblique marker: finğān-ó $=x r-\bar{o} s$, not the last syllable (*finğān-ə-Xrốs). This makes it look more like a Layer II marker rather than a relational noun. The formative $x$ or was also recorded with the Layer II markers $-m \tilde{a}$ and $-k i$. The morpheme(s) xor-ki denotes a complex spatial relation combining source and confinement: "from inside"; sometimes labelled "inelative": kəry-ó xor-ki "from inside the house" (houseOBL heart-ABL). Here again, prosodic considerations would lead one to conclude that $x o r-k i$ is best interpreted as a clitic, and thus as a Layer II case marker because it remains out of the domain of stress: kory-á=xor-ki. This is also suggested by the fact that no oblique marker appears between $x o r$ and $k i$, making it look like a single morpheme. When xor is augmented by inessive -mã, its semantics does not seem to be very different from -mã alone: vyār-ə $x r$-ə-mã walāt-ə $x r$-ə-mã "in town" (town-OBL heart-OBL-IN). A gemination of $/ \mathrm{m} / \mathrm{was}$ also recorded: vyār-ə $x r$-əm-mã. The underlying form in this last example is most likely to be vyār-ə $x r$-ən-mã where $x r$-ən should be interpreted as marked for plural oblique case. The gemination results from the assimilation of $/ \mathrm{n} /$ to $/ \mathrm{m} /$. The morphological structure is thus as follows: town-OBL heartOBL.PL.-IN. In this case too, prosody speaks for clitichood. It should be noted however that xor has retained here its nominal nature because it appears with an oblique marker. This shows that $x o r$ is still between two categories: it kept nominal properties, but also exhibits properties shared with other bound morphemes, most notably clitics. This is also clear evidence that the grammaticalisation process is still under way.

Aleppo Domari makes use of the Turkish morpheme ar- to express "between". It is augmented with the inessive marker -mã: ammat-ə ār-ə-mã "amongst the people" (people-OBL between-OBL-IN). Interestingly, "amongst them" was recorded $\bar{a} r-\vartheta-s \bar{a}-m \tilde{a}$ (between-OBL-3PLIN) and $\bar{a} r-\bar{o}-s \bar{a}-m \tilde{a}$ (between-SG-3PL-IN). The modified noun may also be augmented with 
ablative - $k i$ as shown in (29). The spatial relation "under" is expressed by means of the word bnã, most probably borrowed from Kurdish bin- "under, below": lavr-ē bnã "under the tree", țāwl-ē bnã "under the table". For "above", Aleppo Domari uses the morpheme vatūn: taxt-o vatūn "above the bed".

$\begin{array}{llllll}\text { trōt-o } & q r-\bar{o} S & k \bar{a} & (h) \bar{o} t^{y} \partial r & b k \bar{e} Z & k a(\check{g}) \check{g} \tilde{a} \\ \text { small-OBL } & \text { son-3SG } & \text { FUT } & \text { become.SUBJ.3SG } & \text { good } & \operatorname{man}\end{array}$

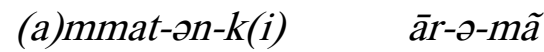

people-OBL.PL-ABL between-OBL-IN

"His young son will become a good man (amongst the people)"

\subsection{Other NP modifiers}

Other nominal modifiers commonly encountered are $\dot{g} \bar{e} r$ "other" (< Arabic $\dot{g} \bar{e} r$ "other"), kōmā"a

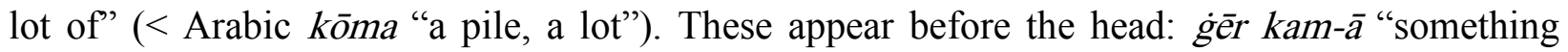
else", kōmā moṣrī "a lot of money". Arabic gèrr seems to be replacing the older morpheme bēvk"other". The latter was recorded in the speech of the oldest informant: nā bēvk-ə ga ̌̆-əs "bring the other man" (bring.IMP.2SG other-OBL man-ACC). The interrogative ktī "how many" may also be used as pre-nominal modifier: ktī sikāra "a couple of cigarettes". This is obviously a case of pattern replication from colloquial Arabic in which the interrogative kam akamm "how many" is also used as a pre-nominal modifier. The combination of the numerals di tron "two three" was also recorded: di tron kamā "a couple of things". The head-noun is also marked with the indefinite marker $-\bar{a} k$. The numeral $d \bar{i}$ "two" may also be postposed to time expressions in the sense of "after, another": $d \bar{i} s-\bar{a} d \bar{i}$ "another day", tīkā $d \bar{i}$ "soon (after a little)", vārs-ā $d \bar{i}$ "after a year, in a year", $d \bar{i}$ tron $d \bar{i} s-\bar{a} d \bar{i}$ "after a couple of days". The inherited quantifier $b \bar{u}$ "a lot" has a rather floating syntax and can appear before or after the noun it modifies: bū ammat ammat bu "many people". The Arabic morpheme wala "not (any)" was borrowed into Domari as a noun determiner: Wala xatrã "never (literally no time)", wala tān-ə-ka "nowhere (literally at no place)" (no place-OBL-AD). The Kurdish determiner har "each, every" appears to be quite common in Aleppo Domari: har kām "everything", har dīs "every day". The morpheme mōr, whose etymology 33 and exact morphological status have still to be uncovered, was also recorded. Its

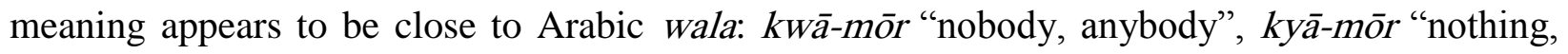
anything", tā-mōr "nowhere, anywhere", mānic-mōr "no hindrance, any hindrance", dōm-mōr "no Dōm, any Dōm". The formative - $\bar{a}-$ in $k y-\bar{a}-m \bar{o} r$ "something, anything" and $k w-\bar{a}-m \bar{o} r$ "someone, anyone" is most probably the short form of the indefinite marker $-\bar{a} k$. The initial elements $k y$ - and $k w$ - are best viewed as allomorphs of the interrogatives $k a y$ "what" and $k \bar{o}$ "who". ${ }^{34}$ Another inherited quantifier is $s \tilde{a}$ "all". ${ }^{35}$ It is always placed after the head. This

\footnotetext{
${ }^{33}$ It may be linked etymologically to Early Romani -moni, described as a "free-choice modifier" (Elšík \& Matras 2006:77-78). However, -moni is generally seen as a borrowing from Greek monos "one".

${ }^{34}$ This is suggested by data from the Domari dialect of Sarāqib (northern Syria) in which the following forms were recorded: $k w-\bar{a} k$-ə-s $\bar{a}$ "with someone" (who-INDEF-OBL-COM), ky-āk-ə-tā "on something" (what-INDEF-OBLSUP).
} 
morpheme is autonomous as far as stress assignment is concerned, suggesting it cannot be considered an affix or a clitic but rather a free morpheme: msiry-ē-m sẫ "all my money", ammat $s \tilde{a}$ "all the people". An interesting behaviour occurs with nouns denoting time reference modified by sã. These were recorded with a suffix whose surface form is $-s$, resembling the Layer I accusative marker: ārātos sã "all night long", dīsəs sã "all day long". It is likely that the underlying form is not $-s$ but $-n$, which would subsequently assimilate to /s/. This is suggested from temporal expressions marked with oblique $-n$ and Layer II superessive -tã as in ārāt-on-tã "in the night", sb-ən-tã "in the morning", zamān-ən-tã "in the past". It is still obscure why ārātəs sã and dīsəs sã would be marked with plural oblique $-n$ without Layer II marker. One possible explanation is that oblique case also serves to mark temporal expressions. ${ }^{36}$ Numerals appear at the left and don't trigger plural agreement on the modified noun: panğ vārs "five years", tron ğib "three languages". Plural agreement is only triggered when the head noun is augmented by bound possessive pronouns: $d \bar{i}$ bēn- $\bar{e}-m$ "my two sisters" (two sister-PL-1SG). As mentioned above, indefiniteness may be overtly marked morphologically (the suffix $-\bar{a} k$ ), or syntactically by a short form of the numeral $y \bar{e} k a$ "one": $y \bar{e} d \bar{i} s-\bar{a}$, and also in speech of some speakers by the

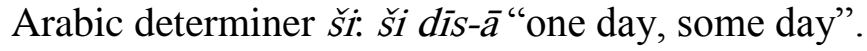

\section{The Verb}

Aleppo Domari has four inflectional categories labelled here perfective, imperfective, subjunctive and progressive. The verb consists of a root, to which various derivational and inflexional morphemes attach. There are simple verbs, and complex verbs. Simple verbs consist of one lexical root, whereas complex verbs consist of an invariable element carrying most of the semantic load and a light verb carrying morphological information. Two light verbs were recorded: $h$-, whose primary meaning is "become" and kar-, whose primary meaning is "do" (see discussion below).

\subsection{Simple verbs}

In the perfective, according to the nature of the last element of the lexical root, certain formatives will be selected: /r/, /d/ and /rd/. The consonant /r/ appears systematically after /î/, while /d/ appears after a consonant. As far as $/ \mathrm{rd} /$ is concerned, it is still unclear what reasons lie behind its selection and it is very likely that any explanatory attempt will have to take a diachronic stand. Diachronically, Domari closely resembles Romani and other Indo-Aryan languages as far as formation of the perfective is concerned, that is the recruitment of the old participle to form the base of the new perfective paradigm. The Old Indo-Aryan past participial marker -it-is the main source of the perfective marker in both Domari and Romani (Matras 2002:138). In Domari, an environment based split into /r/ and /d/ must have occurred. The appearance of $/ \mathrm{rd} /$ may be a later

\footnotetext{
${ }^{35}$ Interestingly, sã did not survive in Palestinian Domari, in which Kurdish gišt is used (Matras, p.c.). Romani also exhibits a cognate form.

${ }^{36}$ Macalister (1914) reports similar forms in Palestinian Domari for which he writes: "Adverbs of time are formed by adding -ăn, -tăn to the substantive: as dīs, day; dîsan, daily; ărát, night; ărátan, nightly; sŭbaḥ, morning; săbáḥtan, in the morning".
} 
development triggered by the structural integration of the light verb kar- to certain lexical roots. There are signs that this process is still active synchronically, as suggested by the verb gā kar"to say", obviously from gāl kar-, whose literal meaning is "make speech" (< gāl "word, speech"; the form gāl kar- is attested in Macalister's material). In contemporary Aleppo Domari, this verb is mostly realised gā kar-, in which /1/ dropped. The root can further shrink, leading to the disappearance of $/ \mathrm{k} /$. So equally possible for "I said" are gā kardōm and gārdōm, as if the lexical root had become $* g \bar{a}-$. This is also suggested by the progressive forms of the verb: $g \bar{a}-$ štōme gā ka-štōme "I'm saying" (say-PROG.1SG, see below for a discussion of the progressive). The subject agreement markers $-\bar{o} m,-\bar{o} r,-\tilde{a},-\bar{e} n,-\bar{e} s,-\bar{e} n d$ attach to the right (see below). What is striking compared to Palestinian Domari is that no gender distinction was recorded for the third person singular. ${ }^{37}$ Also different is the $3 \mathrm{PL}$ marker. ${ }^{38}$ Only the $3 \mathrm{SG}$ agreement marker shows allomorphic variation when object bound pronouns are suffixed: mčo-

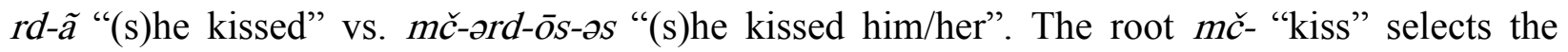
extension $-r d$ - to form the perfective (the central vowel [ə] is epenthetic). The suffixation of the $3 \mathrm{SG}$ object pronoun -əs triggers the allomorph $-\bar{o} S$ instead of $-\tilde{a}$.

\begin{tabular}{|c|c|c|c|}
\hline & $p \overline{I^{-}}$"drink" & ğān- "know" & nang-"enter" \\
\hline 1.SG. & $p \bar{i}-r-\bar{o} m$ & ǧān-d-ōm & nangə-rd-ōm \\
\hline 2.SG. & $p \overline{1}-r-\bar{O} r$ & ǧān-d-ōr & nangə-rd-ōr \\
\hline 3.SG. & $p \bar{i}-r-\tilde{a}$ & ğān-d-ã & nangə-rd-ã \\
\hline 1.PL. & $p \bar{i}-r-\bar{e} n$ & ǧān-d-ēn & nangə-rd-ēn \\
\hline 2.PL. & $p \overline{1}-r-\bar{e} S$ & ğān-d-ēs & nangə-rd-ēs \\
\hline 3.PL. & $p \overline{1}-r-\bar{e} n d$ & ğān-d-ēnd & nangə-rd-ēnd \\
\hline
\end{tabular}

Table 7: Perfective

The imperfective is formed by adding the following subject agreement markers to the base: om(e), - $\bar{e} ;-\bar{o}-,-\partial r(e),-\partial n(e),-\partial s(e)$, -ond(e). The morpheme -e that appears to the right was labelled by Matras (1999:30) a "contextualising marker" (see below). It always appears at the rightmost of the verbal word, that is, if an object pronoun is inserted, it will be placed between the subject marker and -e: amā hass kammor-e (< hass kar-m-ər-e) "I like you". The 2SG has an allomorph - $\bar{o}$ - before bound object pronouns: tō ḥass kar-ō-m-e "you like me". An epenthetic consonant $[v]$ is inserted between the $2 \mathrm{SG}$ subject marker and stems that end in a vowel: byāu- $\bar{e}$ "you fear", pčâv-e-" you ask".

\footnotetext{
${ }^{37}$ Palestinian Domari: gara "he went" vs. garī "she went" and laherda "he saw" vs. laherdī "she saw" (Matras 1999:29). The same distinction is reported by Macalister (1914). Corresponding forms in Aleppo are garã “(s)he went" and lakərdã dakordã "(s)he saw/found".

${ }^{38}$ Aleppo Domari seems to be more conservative in that regard. The form given by Matras (1999:29) in Palestinian Domari is $-e$, most probably a reduction of *-end. However, the consonant /d/ survives in the allomorph -ed- when an object pronoun is suffixed: laherde "they saw" vs. laherdedis "they saw it". Matras does not analyse it as a case of allomorphy but as "a reduplication of the perfective extension" which is "phonologically motivated" (Matras 1999:29). The same allomorph appears also in Matras (2000): mardedis "they killed him"; also most probably analysable as mard-ed-is (kill.PFV-SUB.3PL-OBJ.3SG). The corresponding form in Aleppo Domari would be mārd-ēnd-os.
} 


\begin{tabular}{|c|c|c|c|}
\hline & $p \overline{1}-" d r i n k "$ & ǧān- "know" & nang- "enter" \\
\hline 1.SG. & py-ome & ǧān-əme & nang-əme \\
\hline 2.SG. & $p y-\bar{e}$ & ǧān-ē & nang-ē \\
\hline 3.SG. & py-ore & ğān-ore ğārre & nang-ore \\
\hline 1.PL. & py-one & ğān-əne & nang-one \\
\hline 2.PL. & py-əse & ğān-əse & nang-əse \\
\hline 3.PL. & py-onde & ǧān-ənde & nang-onde \\
\hline
\end{tabular}

Table 8: Imperfective

The subjunctive typically consists of the root, to which the imperfective subject markers attach, but without the "contextualising marker" $-e$. In the $2 \mathrm{SG}$, the ending $-\bar{a}$ appears instead of $-\bar{e}$. When bound object pronouns are suffixed, the morpheme seems to split into two parts: kar- $\bar{o}-S-\bar{a}$ "(that) you make it" (possibly make-SUBJ.2SG-OBJ.3SG-SUBJ).The subjunctive of $p \bar{i}$ - and ğān- is thus totally predictable. However, a certain number of roots behave differently and see the insertion of the suffix $-\check{c}$ - between the root and the subject markers. This is the case of nang-, whose stem becomes nangə- $\breve{c}$. It may seem from this ordering that the subjunctive is derived from the indicative by way of subtractive morphology. In the case of verbs like pi-and ğān-, it is of course better to view the imperfective as derived from the subjunctive as it simply involves the suffixation of the so-called "contextualising marker" $-e$. However, this is impossible with verbs which require the suffixation of $-\bar{c}$ - between the root and the subject markers, hence the need to posit three different stems for each inflectional category. The suffix $-\check{c}$ - is a feature encoded in the lexicon as there seems to be no rule that permits to predict its presence or absence. Some verbs may appear with or without it. These is the case for the root $\bar{a} v$ - "to come" for which three forms were recorded, two are zero-marked and one marked with $-\bar{c}$-: $\bar{a} v$-or $~$

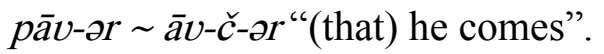

\begin{tabular}{|c|c|c|c|}
\hline & $p \overline{I^{-}}$"drink" & ǧān- "know" & nang- "enter" \\
\hline 1.SG. & py-əm & ǧān-əm & nangə-̌̌-əm \\
\hline 2.SG. & $p y-\bar{a}$ & ǧān-ā & nangə- $\check{c}-\bar{a}$ \\
\hline 3.SG. & $p y$-ər & ğān-ər & nangə- $\check{c}$-ər \\
\hline 1.PL. & $p y$-ən & ğān-ən & nange- $\check{c}$-on \\
\hline 2.PL. & $p y$-əS & ğān-əS & nange- $\check{c}$-əS \\
\hline 3.PL. & py-ond & ğān-ond & nangə-č-ənd \\
\hline
\end{tabular}

Table 9: Subjunctive

In the speech of one informant, the subjunctive suffix was constantly realised $\left[\mathrm{t}^{\mathrm{y}}\right]$. It is still unclear whether $[\mathrm{t} f]$ comes from $\left[\mathrm{t}^{\mathrm{y}}\right]$ or the other way around. According to Matras (1999:32-33), $-\check{c}$ - (- $\check{s}$ - in Palestinian Domari) comes from the integration of the auxiliary (a) $\check{c} \check{c} h$ - "to stay" to the verbal base. If this turned out to be valid, [t] ] would be the original form, whereas $\left[\mathrm{t}^{\mathrm{y}}\right]$ would be a later development. Verbs whose roots end in /s/ and select $-\check{c}$ - in the subjunctive exhibit the cluster /št/: vēšt- (<vēs- "stay"), rāštt- (<rāss "arrive"), nāšt- (< nās- "quit"). 
The imperative bears morphological similarities with the subjunctive. For verbs like $p \bar{i}$ - and ğān, the 2SG simply consists of the lexical base: pī ! “drink!”, ğān ! "know!”, kar ! "do!”; whereas the 2PL is identical to the 2PL subjunctive: $p y$-əs "drink (PL.)!", ğān-əs ! "know (PL.)!", kar-(ə)s! "do (PL.)!". For verbs that require the suffix - $\check{c}$ - in the subjunctive, the 2SG is formed by adding -tī to the root: lak-tī "look!", while the 2PL is identical to the subjunctive: lak$\check{c}$-əs! "look (PL.)!". For other persons, the subjunctive suffices to express invitation or order: $\check{s} t \overline{1}$ ǧān "get up (and) let's go!" (get.up.IMP.2SG go.SUBJ.1PL). This being said, some discrepancies between the subjunctive and the imperative were recorded in some irregular verbs.

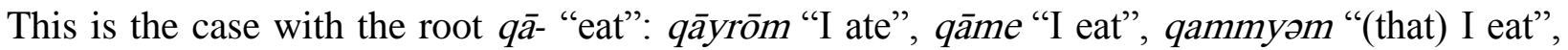
qaymī "eat!" (plural qammyəs); $\bar{a} v$ - "come": āyrōm "I came”, āvome "I come", āvom pāv-əm $\bar{a} v$-č-om "(that) I come", pā "come!" (plural pāvos); ga- "go": garōm "I went", ğāme "I go", ǧām "(that) I go", ğu "go!” (plural ğāss); nē- "take": nērōm "I took", nēme "I take", nēm "(that) I take", pnē "take!" (plural not recorded); tōm "I gave" (totã "he gave"), dēme "I give", (b)dēm "(that) I give", bdē "give!". Rather marginal in Aleppo Domari are the formatives 1 - and $p$ - for the subjunctive. The former was only recorded twice with the verb pi- and vāy- "hit": lo-pyər "that (s)he drinks", $k \bar{a}$ l-vā-m "I will hit", $k \bar{a}$ l-vy-ā "you will hit"; while the latter was only recorded in the imperative of $t \bar{o}-/ d \bar{e}-$ "give" and $n \bar{e}-$ "take": pnē! "take", bde "give!" 39 (/p/ undergoes voicing).

Peculiar to Aleppo Domari (and probably to northern varieties of Domari) is the extension $\check{s} t$ - added to the root to express progressive aspect: qāa-št-ōme ( qāštōme) "I'm eating" (eatPROG-1s). This may be an important isogloss that distinguishes northern Domari from southern Domari, since no reference to it is made neither by Macalister nor by Matras. With stems ending in a consonant, a stressed epenthetic vowel /i/ /1/1 is added: ān-išt-ōme "I'm bringing". After the

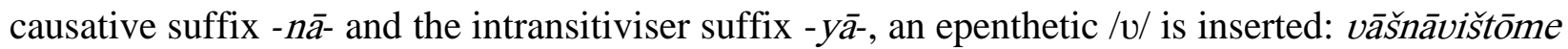
"I'm burning (transitive)", quḥhyāvištōme "I'm coughing". The subject agreement markers ome, -öre, -e, -inne, -isse, -inde are the same as the copula "be". The 3SG marker has the

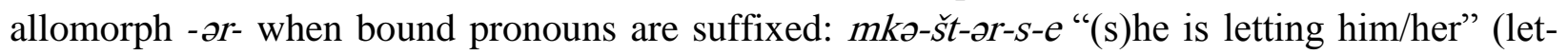
PROG-SUB.3SG-OBJ.3SG-CM), mār-ǐ̌t-or-s-e "it/(s)he is killing him/her" (kill-PROGSUB.3SG-OBJ.3SG-CM). The morpheme $-e$ at the end is the so-called "contextualising marker" (see below). The verb kar- "do" inflects as follows (/r/ drops, most probably to avoid a heavy three consonant cluster):

\begin{tabular}{|c|c|}
\hline 1.SG & ka-št-ome \\
\hline 2.SG. & ka-št-ōre \\
\hline 3.SG. & $k a-\check{s} t-e$ \\
\hline 1.PL. & ka-št-inne \\
\hline 2.PL. & $k a-\check{s} t-i s s e$ \\
\hline 3.PL. & ka-št-inde \\
\hline
\end{tabular}

Table 10: Progressive of kar- "do"

\footnotetext{
${ }^{39}$ Interestingly, the formative $l$ - is quite frequent in Patkanoff's material (Patkanoff 1907/1908: 260-261): lafgynam "(that) I buy" (Aleppo fiknom), lipar "buy!" (Aleppo pār). It was also recorded more systematically in the Domari dialect of Beirut.
} 
When associated with negation, the progressive form of the verb can also convey a volitive

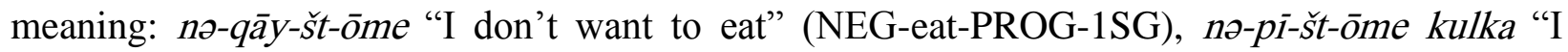
don't want to drink anything" (NEG-drink-PROG-1SG anything), n-ğāa-šte korī "(s)he doesn't want to go home" (NEG-go-PROG.3SG).

\subsection{Complex verbs}

Aleppo Domari is not very eccentric as far as complex verbs are concerned as it exhibits patterns widely attested in neighbouring languages. ${ }^{40}$ That is the use of a light verb that carries morphosyntactic information added to an invariable lexical element that plays the role of semantic nucleus. There seems to be only two light verbs in Domari: $h$ - "become" and kar- "do". Interestingly, this is a commonality with Kurdish (and other neighbouring languages) which also possesses the two light verbs kirin "do" and bûn "be, become" (Haig 2007:174). The verbs $h$ and $k a r$ - respectively inflect as follow for the perfective, imperfective and subjunctive:

\begin{tabular}{|l|l|l|l|}
\hline & Perfective & Imperfective & Subjunctive \\
\hline 1.SG. & hrōm & hōme & hōčom \\
\hline 2.SG. & hrōr & $h \bar{o} \bar{e}$ & hōča \\
\hline 3.SG. & hrã & hōre & hōčor \\
\hline 1.PL. & hrēn & hōne & hōčon \\
\hline 2.PL. & hrēs & hōse & hōčos \\
\hline 3.PL. & hrēnd & hōnde & hōčond \\
\hline
\end{tabular}

Table 11: Inflections of $h$ - "become"

\begin{tabular}{|c|c|c|c|}
\hline & Perfective & Imperfective & Subjunctive \\
\hline 1.SG. & kardōm & karme & karom \\
\hline 2.SG. & kardōr & karē & karāa \\
\hline 3.SG. & kardã & karre & karor \\
\hline 1.PL. & kardēn & karne & karən \\
\hline 2.PL. & kardēs & karse & karəs \\
\hline 3.PL. & kardēnd & karonde & karond \\
\hline
\end{tabular}

Table 12: Inflections of kar- "do"

Of non-Arabic origin, the corpus provides only two items: amīš h- "go down" and ğirsā h- "to marry ${ }^{41} "$. Arabic elements integrated into Domari through the use of $h$ - are very easy to find. This is thus a very productive device to expand the lexicon. Examples are 'ĩ̌ $h$ - "live" (Arabic $y$ -

\footnotetext{
${ }^{40}$ See Wohlgemuth (2009:102-117) for a cross-linguistic account of the light verb strategy.

${ }^{41}$ Aleppo Domari possesses two different expressions for "marry", depending on gender: when addressing a woman, monos kar- (lit. "make husband") can be employed, while the verb ğirsā $h$ - can be used invariably when addressing both a man or a woman.
} 
iٓ̌s "he lives"), fomm $h$ - "understand" (Arabic yi-fham "he understands"), Itaqi $h$ - "meet" (Arabic yi-ltaqi "he meets"), balliš h- "start" (Arabic $y$-balliš "he starts"), zūr $h$ - "visit" (Arabic $y$-zūr "he

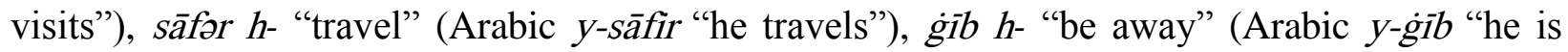

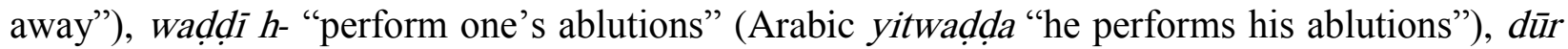
$h$ - "go round" (Arabic $y$-dūr "he goes round"). Two other verbs that were recorded only in the imperative and whose etymology is still obscure ought to be mentioned: mātol (h)ôti "lean!" and hoss (h)ōti "shut up!". As mentioned above, the consonant /h/ is highly unstable in Aleppo Domari and surfaces only in very careful speech. This is apparent in the verb fohm $h$ - in which the consonant $/ \mathrm{m} /$ also undergoes compensatory gemination because of the elision of $/ \mathrm{h} /:$ fohm $\rightarrow$ fomm. The initial $/ \mathrm{h} /$ of the light verb is also elided, as shown in the following example: tō fomm $\bar{o} \bar{e} g \bar{a} l$ ? "Do you understand what I'm saying?" (you understand.IMPFV.2SG speech). There are two reasons to consider that the light verb and the semantic nucleus are two separate words. The first reason pertains to prosody and the second is morphosyntactical. As far as prosody is concerned, the two elements are two distinct phonological words because they both carry primary stress: $k \bar{a}$ gíb (h)ōč́m "I will be away" (FUT travel.SUBJ.1SG). Morphosyntactically, evidence for the non-integration of the two elements into one unit is provided by negation. There are two negation prefixes: $n$ - and $m$-. The prefix $m$ - is restricted to the negation of the imperative and subjunctive, whereas $n$ - serves in all other contexts. With simple verbs, both prefixes attach to the right of the verbal word. With complex verbs, they attach to the right of the light verb, suggesting that there is no structural integration between the

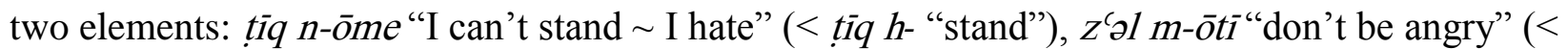
$z^{\prime}$ 'l h- "be angry").

The other light verb attested in Aleppo Domari is kar- "do". Complex verbs involving inherited elements are easier to find than with $h-:$ akkī kar- "wait" (akkī "eye"), ğib kar- "speak" (ğib "tongue"), mangī̌s kar "beg" (mang- "ask"), lagī̌s kar- "quarrel" (lagī̌s" "quarrel"), kām kar"work" (kām "work"). As with $h$-, integration of Arabic elements is also very common with kar=: saddiq kar- "believe" (Arabic y-șaddiq "he believes"), mdah kar- "praise" (Arabic yi-mdah "he praises"), dfiš kar- "push" (Arabic yi-dfǐs" "he pushes"), sakkir kar- "close" (Arabic y-sakkir "he closes"). These examples suggest that the imperfective stem of Arabic verbs is used for their integration into Domari. Here also phonological and morphosyntactical arguments tend to conclude that the light verb and the lexical element do not form one single unit. Examples involving the negation marker $n$ - are: hass nə-karme "I don't like", lvā n-karme "I don't open", saddiq nə-karməre "I don't believe you". Surprisingly enough, it was not conclusive with the marker $m$ - and the verb ǧib kar- "speak": mo-ğib kar! "don’t speak!". More elicitation is here needed to test each verb with both markers $n$ - and $m$-. It is still partially unclear on what line Arabic verbs are integrated as the choice of kar- or $h$ - does not seem to be motivated by bare transitivity. All kar-verbs are indeed transitive, but so are many $h$-verbs: šakkər (h)rōs-əm "he thanked me". One possible explanation is the degree of transitivity of the loan verb and the semantic role of the object. One such a scale is provided in Tsunoda (1985:388): (1) direct effect on patient, (2) perception, (3) pursuit, (4), knowledge, (5) feeling, (6) relationship, (7) ability. Further evidence of this is provided by the pair xsir h- (< Arabic xisir) and dayya ${ }^{\prime}$ kar- $(<$ Arabic dayya 9 which both mean "lose". In Arabic, these verbs are not exactly interchangeable and there is a slight semantic contrast: xisir mașāri "he lost money (in a transaction)" vs. ḍayya' mașāri 
"he lost money (while walking or forgot it somewhere)". Beyond this semantic contrast and while the two verbs are obviously transitive, they also exhibit a difference that pertains to the degree of transitivity: xisir can have an object, whereas dayya' must have an object. This may explain why xisir is borrowed into Domari through $h^{-}$, and dayya'through kar-. On the whole, the light verb strategy is a very convenient way of integrating new lexical elements into the language. This strategy is so productive that it seems sometimes to be employed in an ad hoc manner to create new verbs that may not be part of the lexicon, as suggested by the following example: tō xīb kardōr amal-ōm "you disappointed me" (2SG disappoint do.PFV.2SG hope$1 \mathrm{SG})$. This is an extreme case of replication from the Arabic idiom xayyabt amal-i "you disappointed me" involving the verb xayyab "disappoint", a causative derivation of the triconsonantal root $x-y-b$ "to fail" and the noun amal "hope". The idiom xayyabt amal-i thus literally means "you made my hope go wrong". When replicating this idiom into Domari, the speaker retrieved from Arabic the imperfective stem of the non-causative form $x \bar{i} b$ ( $y$ - $x \bar{i} b$ "it goes wrong"; 3SG-go.wrong.IMPFV) to which he added the light verb kar-, used most commonly to integrate verbs that locate high on the transitivity scale. The noun amal "hope" was also copied as such.

\subsection{Valency changing morphology}

In the current state of knowledge, Aleppo Domari, like Palestinian Domari (Matras 1999:28) has two valency adjustment suffixes: one increasing, labelled here "causative suffix", and one decreasing, labelled here "passive suffix". These suffixes appear right after the lexical root. The

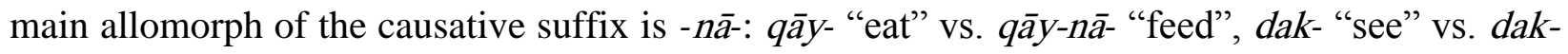

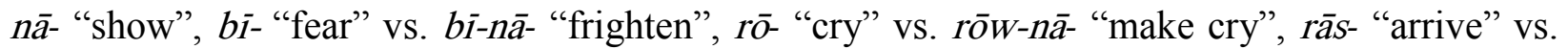

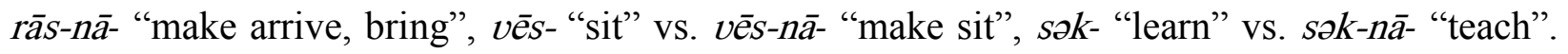

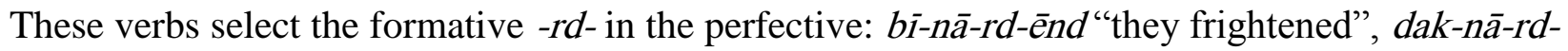
ã "he showed". Imperfective subject agreement markers attach directly after the causative suffix: $v \bar{e} s-n \bar{a}-r$-e "(s)he makes sit". The subjunctive stem is the same as the imperfective and the subjunctive suffix - $\check{c}$ - is never inserted: $k \bar{a}$ rās-nā-m-ər "I'll drive you back" (FUT arrive-CAUSSUB.1SG-OBJ.2SG). As mentioned above, an epenthetic $/ v /$ is added between the causative suffix and vowel initial morphological material that appears to the right, in order to avoid hiatus: dak-nāv-ište "(s)he's showing". The other allomorph of the causative suffix recorded is - $\bar{a}-$ and seems to be restricted to complex verbs formed with kar-. Only one instance was found in the corpus with the verb zivrā kar- "forget" whose causative is zivrā kar-ā- "make forget". The

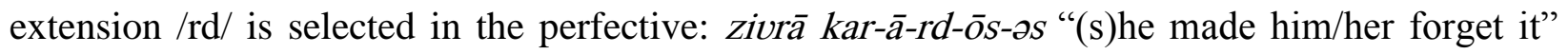
(forget make-CAUS-PFV-SUB.3SG-OBJ.3SG). In the imperfective, the subject agreement marker normally attaches to the right of the causative suffix: zivrā kar-ā-r-m-e "it makes me forget" (forget make-CAUS-SUB.3SG-OBJ.1SG-CM). No instances of subjunctive were recorded. The allomorph -rā-was recorded once in the verb pērā- "bring back", probably derived

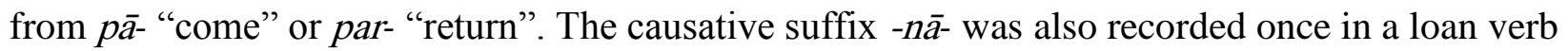

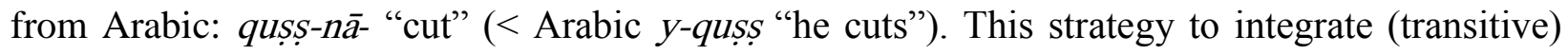
loan verbs into Domari does not seem to be productive anymore since the most common one appears to be the light verb strategy (see above). 
The passive suffix has two main allomorphs: $-\overline{\bar{l}}$ - in the perfective and $-y \bar{a}$ - in the imperfective. The productivity of the passive derivation cannot be assessed with certainty as it was only tested from Arabic items, a language that behaves quite different from European languages in which passives are quite common. Recorded items are $d \bar{o}-$ "wash" vs. $d \bar{o} w \bar{i}_{-}^{-}$"be washed", qaft- "steal" vs. qaftī- "be stolen", ğān "know" vs. ǧānī- "be known”, fkən- "sell” vs. foknī- "be sold”. The scope of this suffix goes beyond bare passivisation and it can act also as an intransitiviser: čār"hide (transitive)" vs. čārī- "hide (intransitive)". The perfective selects the extension -r-: qafțīrã "it was stolen", ğānirre "it's known”. In the imperfective, the passive suffix takes the shape -yā-, to which subject agreement markers attach: čār-yā-m-e "I hide (intransitive)" (hide-PASS-1SG$\mathrm{CM}$ ). In the subjunctive, the suffix $-\check{c}$ - is inserted between the passive marker and the subject agreement morpheme: $k \bar{a}$ čār-yā-č-əm "I'm going to hide" (FUT hide-PASS-SUBJ-1SG). The

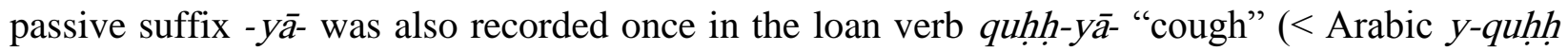
"he coughs"). ${ }^{42}$ This parallels the use of causative -nā- to integrate transitive verbs into Domari lexicon and suggests that at some point the integration of foreign elements could be made through the suffixation $-n \bar{a}$ - for transitive verbs and $-y \bar{a}-$ for intransitive verbs. The paucity of data does not allow much speculation about the exact status of this strategy in comparison to the light verb strategy.

Valency changing operations on complex verbs involves the permutation of the light verb: the causativisation of a $h$ - verb leads to the replacement of $h$ - by kar-and the passivisation of kar- verbs leads to the replacement of kar- by $h$-: zivrā kar- "forget" vs. zivrā $h$ - "be forgotten", (a)mīs $h$ - "go down" vs. (a)mīš kar- "bring down". While the causative derivation was recorded with a kar- verb (zivrā karā- "make forget"), no $h$ - verb was recorded with a passive derivation. Although this cannot be ruled out on pure formal grounds (some $h$-verbs are transitive), it is however not attested in the collected lexicon.

\subsection{Tense}

The rightmost slot of the Domari verb can be occupied by what Matras (1999:30) calls the "contextualising marker" and the "de-contextualising remoteness marker" (respectively in Palestinian Domari $-i$ and $-a$ ). He further notes that the former figures in the present (here labelled imperfective), and in the perfect (here labelled perfective), noting that "its function is the actualisation of an action or its result within the currently activated context of the speech event". In Aleppo Domari, the contextualisation marker is realised $-e$ and denotes a general or habitual present when it marks the imperfective stem, as shown in (30).

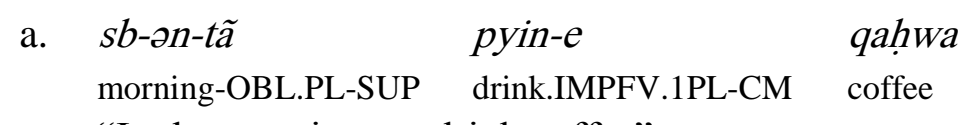

"In the morning we drink coffee"

\footnotetext{
${ }^{42}$ Surprinsingly, this verb cannot have been borrowed from Aleppo Arabic in which the form yi-s $u l$ is used instead of $y$-quhh. This latter presumably occurs in the surrounding rural varieties.
} 


\section{b. qtor-e tambūr $-\bar{e}-t \tilde{a} \quad b k \bar{e} Z$ \\ play.IMPFV.3SG-CM oud-OBL-SUP well \\ "He plays oud (traditional instrument) well"}

When the contextualising marker attaches to the perfective stem, it denotes a perfect, as shown by the following pair: $p \overline{1}-r-\bar{o} m$ "I drank" (drink-PFV-1SG) vs. $p \bar{i}-r-\bar{o} m-e$ "I've drunk = as I speak, I've drunk" (drink-PFV-1SG-CM), vēs-r-ōm "I stayed" (stay-PFV-1SG) vs. vēs-r-ōm-e "I'm settled, I live" (stay-PFV-1SG-CM). In the 3SG, the marker $-e$ simply replaces the perfective

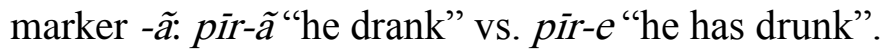

As for the remoteness marker, Matras describes it as a device "to emphasize the demarcation between the action conveyed by the verb, and the currently activated speech context" (Matras 1999:30). Aleppo Domari has two allomorphs that seem to be in free variation: - $a$ (also realised a) and $-\bar{a} \bar{s} i$. The latter is strikingly similar to the reconstructed proto-Romani remoteness marker as(i) (Matras 2002:154). It can attach to the imperfective stem (31a), denoting most prototypically a habitual past; to the progressive stem (31b), denoting a progressive past; to the perfective stem (30c), denoting a pluperfect. Surprisingly, the remoteness marker was also recorded after the subjunctive stem (31d). This last option, as far as documented, seems impossible in Palestinian Domari.

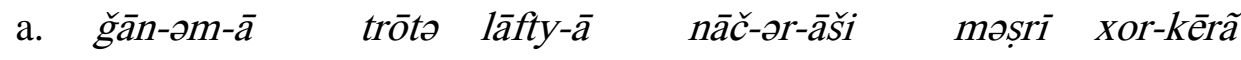 know-1SG-RM small girl-INDEF dance-3SG-RM money for
"I knew a girl (who) would dance for money"
b. ǧib ka-štt-̄ā vāšyān
language do-PROG.3SG-RM COM.3PL
"(S)he was speaking with them"
c. qabəl-māa rāšton kəry-ə-ki kənd-ā before arrive.SUBJ.1PL house-OBL-ABL leave.PFV.3SG-RM "Before we got back home, (s)he had left"
d. $\quad k \bar{a} \quad s \bar{a} f \partial r(h) \bar{o} c ̌ o m-\bar{a} \quad \bar{e} \quad$ tron nārn-ə-Sa vyār-ə-ki FUT travel.SUBJ.1SG-RM this.OBL three man-OBL-COM town-OBL-ABL "I wanted to go to town with these three men"

Overall, the morphological structure of the verbal word in Aleppo Domari is the same as in Palestinian Domari as described by Matras (1999:29): stem - derivation - aspect/mood - subject object - tense, although there are significant differences as far as forms are concerned.

\subsection{Modality}

The expression of modality in Aleppo Domari does not differ greatly from what can be found in Palestinian Domari. Two inherited roots survived: sāk- "can, be able" (< Old Indo-Aryan śákya 
"possible") and mang- "ask, want" (< Old Indo-Aryan mārgana "asking"). The verb sāk- inflects as follows in the perfective and imperfective (no subjunctive was recorded):

\begin{tabular}{|l|l|l|}
\hline & Imperfective & Perfective \\
\hline 1.SG. & $s \bar{a} k$-əme & $s \bar{a} k \partial-r d-\bar{o} m$ \\
\hline 2.SG. & $s \bar{a} k-\bar{e}$ & $s \bar{a} k \partial-r d-\bar{o} r$ \\
\hline 3.SG. & $s \bar{a} k$-əre & $s \bar{a} k \partial-r d-\tilde{a}$ \\
\hline 1.PL. & $s \bar{a} k$-əne & $s \bar{a} k \partial-r d-\bar{e} n$ \\
\hline 2.PL. & $s \bar{a} k$-əse & $s \bar{a} k \partial-r d-\bar{e} s$ \\
\hline 3.PL. & $s \bar{a} k$-ənde & $s \bar{a} k \partial-r d-\bar{e} n d$ \\
\hline
\end{tabular}

Table 13: Inflections of $s a \bar{k}$ - "be able"

As shown above, the perfective selects the extension - $r d$-, unlike Palestinian Domari which exhibits $-r-{ }^{43}$ The semantic scope of $s \bar{a} k$ - is rather large and it may be used to express possibility, capacity and permission. When complemented by a clause, the verb in the subordinate clause is always in the subjunctive: $n$-sākme skot"om "I can't study" (NEG-be.able.IMPFV.1SG study.SUBJ.1SG). Another way of expressing capacity/possibility is to use the verb $h$ "become": n-(h)ōre ğās dāwat-ə-ki "You (PL.) can't go to the wedding" (NEGbecome.IMPFV.3SG go.SUBJ.2PL wedding-OBL-ABL). This use of the verb "become" to express possibility is actually quite common in the languages of the area. ${ }^{44}$ The verb manginflects as follows in the the perfective, imperfective and subjunctive:

\begin{tabular}{|c|c|c|c|}
\hline & Perfective & Imperfective & Subjunctive \\
\hline 1.SG. & mangə-rd-ōm & mangome & 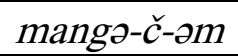 \\
\hline 2.SG. & mangə-rd-ōr & mangē & mangə- $\check{c}-\bar{a}$ \\
\hline 3.SG. & mangə-rd-ã & mangore & mangə-̌̌-ər \\
\hline 1.PL. & mangə-rd-ēn & mangone & mangə-̌̌-ən \\
\hline 2.PL. & mangə-rd-ēs & mangəse & 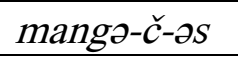 \\
\hline 3.PL. & mangə-rd-ēnd & mangonde & mangə-̌̌-ənd \\
\hline
\end{tabular}

Table 14: Inflections of mang- "ask"

Like $s \bar{a} k$-, the verb mang- selects the extension $-r d$ - in the perfective, and $-\check{c}$ - in the subjunctive. The original meaning of the root "ask, require" was kept as the primary meaning in Domari: nəsākordã mangəť or dīšōm moṣrī “(s)he couldn't ask me for some money” (NEG-can.IMPFV.3SG ask.SUBJ.3SG ABL.1SG money). When followed by a subordinate clause, mang- is closer to a control verb. The verb of the subordinate clause appears in the subjunctive: mangordōm dīš̄ $k ə n t$ " house-ABL-OBL). The expression of volition was recorded a couple of times with the imperfective stem of the verb mang-: mangəme abōr pērām miṣry-ən șəbã "I wish to give you

\footnotetext{
${ }^{43}$ Matras (1999:33) gives the following forms: sakamil sakarōm "I can/could".

${ }^{44}$ Cf. Arabic mā biṣir (NEG become.IMPFV.3SG) or (colloquial) Persian ne-miše (NEG-become.IMPFV.3SG) that both mean "it's not possible".
} 
back the money tomorrow" (ask.IMPFV.1SG for.2SG return.SUBJ.1SG money-ACC.PL tomorrow). Very common, though, in Aleppo Domari is the progressive root of mang- to express desire: mangī̌stōme pānī "I want water" (ask.PROG.1SG water). Its use may also extend to cases in which one would expect the future marker $k \bar{a}$, that is when the main clause and the subordinate clause share the same subject: mangīšte hōty or zangīl "he wants to become rich" (ask.PROG.3SG become.SUBJ.3SG rich). When the subject is not shared, the use of $k \bar{a}$ is impossible and the progressive form of mang- is the only option: mangīštōme ğār "I want him to go" (ask.PROG.1SG go.SUBJ.3SG). The paucity of data does not allow any conclusive statement but it seems that the extension of the progressive form of mang- to contexts so far reserved to $k \bar{a}$ may be a sign of language change, most probably triggered by contact. Indeed, one may suppose that the use in Levantine Arabic of one single inflected morpheme (bidd-) for both same-subject and different-subject in 'want' complements prompts innovative speakers of Aleppo Domari to replicate the use pattern found in Arabic, drawing on an existing structure (the progressive of mang-). Besides the two inherited roots sāk- and mang-, Aleppo Domari makes extensive use of Arabic borrowed morphemes to express obligation and possibility: lāzim "must", ğbāri "obliged", yimkin balki "maybe". Except for lāzim, these are best interpreted as predicate modifying adverbs because they do not trigger the use of the subjunctive. Compare for that matter: lāzim kənt" əm "I must leave" (must leave.SUBJ.1SG), vs yimkin ğāme vyār "I may go to town" (maybe go.IMPFV.1SG town).

\subsection{The future marker $k \bar{a}$}

The morpheme $k \bar{a}$ (glossed here FUT) appears as a preverbal modifier. Its primary meaning is volitive (32a) and it is always followed by the subjunctive form of the verb. The volitive meaning has been extended to future reference $(32 b)$.
a. $k \bar{a} \quad p \check{c} \bar{a} m-\partial S$
$k s \bar{e}$
(e) hānī
kardã
FUT ask.SUBJ.1SG-3SG why so
do.PFV.3SG
"I want to ask him why he did this"

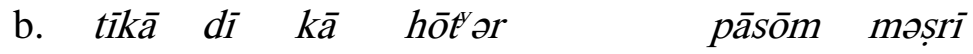
few two FUT become.SUBJ.3SG AD.1SG money
"Soon enough, I'll have money"

Etymologically, $k \bar{a}$ seems to be the grammaticalised form of the root $k \bar{a} r$ - "want" whose inflection was recorded as follow: kārme "I want", kārre "you want", kārse "(s)he wants", kārmāne "we want", kārrāne "you (PL.) want", kārsāne "they want". It can behave like a transitive verb: amīn kārmāne sīkāra "we want a cigarette" (we want.1PL cigarette); or a modal auxiliary: kārsāne pyind pānī "they want to drink water" (want.3PL drink.SUBJ.3PL water). It is of course this latter usage that must have given rise to the invariable form $k \bar{a}$. It is still unclear where this form comes from as it appears to be morphologically half way through between a verb and a noun. As a noun, one would have expected the number suffix $-\overline{o^{-}}$(or $-\bar{e}-$ ) between the root and the bound pronoun *kār- $\bar{o}-m e$. The form $k \bar{a} r-m-e$ is morphologically compatible with a verb, 
as $k \bar{a} r$ - would be the root, $-m$ - the $1 \mathrm{SG}$ subject agreement marker, and -e the contextualising marker. This, however, does not hold true anymore for the plural forms kār-mān-e, kār-rān-e, kar-sān-e, in which the morphemes -mān-, -rān- and -sān- are obviously the plural forms of the object/possessive bound pronouns. The last element $-e$ would then have to be interpreted as the 3SG copula and a form like kār-mān-e would then mean something close to "our desire is". This would be very similar to the morphosyntactical uncertainty around the Levantine Arabic pseudoverb bidd-, which exhibits nominal properties as well as verbal properties, hence its classification as a pseudo-verb. Although $k \bar{a}$ is the outcome of the grammaticalisation of $k \bar{a} r$ - into a future tense marker through erosion, it did not turn into a bound morpheme and remains an independent word. This is evidenced by the fact that although $k \bar{a}$ is placed most often to the left of the verb, material can be inserted between $k \bar{a}$ and the verbal word: $k \bar{a}$ toktōr (h)ōósm "I'll become a doctor". The same holds with negation, the morpheme $m$-is prefixed to the verb, not to $k \bar{a}: k \bar{a}$ mə-kənčəm "I will not go out" (FUT NEG-go.out.SUBJ.1SG). With complex verbs, $k \bar{a}$ appears also to the left: kā sakkir karəm šibbāk-ēs "I'll close the window" (FUT close.SUBJ.1SG window-ACC), kā (a)mīš (h)ōčsm vyār "I'll go down to the market" (FUT go.down.SUBJ.1SG market). The marker kā is formally very similar to the future tense marker found in many Balkan dialects of Romani. Romani $k a$ is usually seen as the outcome of the grammaticalisation of the root kam- "want", under the influence of Balkan languages in which future tense markers commonly originate from the verb "want" 45 . Aleppo Domari obviously underwent the same process, as shown above: the root $k \bar{a} r$ - "want" grammaticalised into a future tense marker. It is most likely that the development of Domari kār-and Romani kam- into ka are two separate developments. As hinted above, models for such a contact-induced grammaticalisation in the case of Aleppo Domari is readily available in Levantine Arabic, in which the pseudo-verb bidd"want" is often used as an auxiliary to denote future reference. Moreover, while the etymology of Romani kam- is rather straightforward (< Indo-Aryan kāma "wish, love, sexual love"), it is still unclear what the exact etymology of Domari $k \bar{a} r$ - is.

\section{Non-Verbal Predication and Related Constructions}

\subsection{The copula}

Aleppo Domari makes use of the root $\check{s} t$ - "be" in non-verbal predication (except in the $3 \mathrm{SG}$, see below). The subject agreement marker - $\bar{o} m$, $-\bar{o} r$, -e (or $\varnothing$ depending on the analysis), -inn, -iss, ind are followed by the contextualising marker $-e$, denoting present tense, or the remoteness marker $-\bar{a}(\breve{s} i)$, denoting past tense:

\footnotetext{
${ }^{45}$ Matras (2002:157-158). See also Boretzky (2003:68). Syntactically, it behaves, differently though, as the negation marker is placed before ka: na ka kerel "he will not do" (Boretzky 2003:68).
} 


\begin{tabular}{|l|l|l|}
\hline & Present & Past \\
\hline 1.SG. & $\check{s} t-\bar{o} m-e$ & $\check{s} t-\bar{o} m-\bar{a}(\check{s} i)$ \\
\hline 2.SG. & $\check{s} t-\bar{o} r-e$ & $\check{s} t-\bar{o} r-\bar{a}(\check{s} i)$ \\
\hline 3.SG. & $-e$ & $-\bar{a}(\check{s} i)$ \\
\hline 1.PL. & $\check{s} t-i n n-e$ & $\check{s} t-i n n-\bar{a}(\check{s} i)$ \\
\hline 2.PL. & $\check{s} t-i s s-e$ & $\check{s} t-i s s-\bar{a}(\check{s} i)$ \\
\hline 3.PL. & $\check{s} t-i n d-e$ & $\check{s} t-i n d-\bar{a}(\check{s} i)$ \\
\hline
\end{tabular}

Table 15: The Copula št- "be"

The root $\check{s} t$ - is often reduced to $\check{S}$ - in the plural forms and one will most often hear $\check{S}$-inn-, $\check{S}$-issand $\check{s}$-ind-. In the speech of one informant, the root $\check{s} t$ - also dropped in the 2PL: tmārinn êtā =isse "you (PL.) are here", èta nisse "you (PL.) are not here". After a vowel, an epenthetic /y/ is inserted between the predicate and 3SG -e: $\bar{e} t \bar{a}=y e$ "he's here". Plural agreement is most conspicuous with animate referents: mām-ōm čàgìn zangīl=ištinde "my cousins are rich" (uncle-1SG children rich=COP.3PL). With inanimate referents, singular agreement is frequent: $\bar{e}$

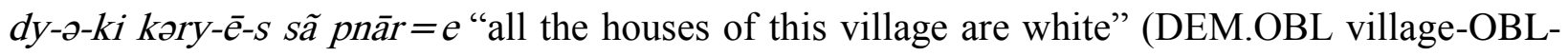
ABL house-PL-3SG all white=COP.3SG). Future reference is expressed with the subjunctive stem of the root $h$ - "become": şəbã tō kəry-ə-m kā hōča "tomorrow you'll be home" (tomorrow you house-OBL-IN FUT become.SUBJ.2SG). The future marker $k \bar{a}$ is optional: søbã kəry-ə-m (h)ōčom "tomorrow I'll be home" (tomorrow house-OBL-IN become.SUBJ.1SG). Syntactically, as shown in the examples above, the copula always appears right after the predicate. After a consonant, a stressed epenthetic /i/ is inserted between the predicate and the copula: gāy-íštome "I'm fine".

\subsection{Existential and possessive constructions}

Existential clauses in Aleppo Domari are introduced by way of the morpheme ašt "there is", as exemplified in (33a). The remoteness marker $-\bar{a}(\check{S} \check{i})$ is suffixed to ašti to denote past reference (33b).
a. pāny-ə-m wāt ašti water-OBL-IN stone there.is
"There is a stone in the water"
b. bū ammat ašt-āši vyār-ə-mã many people there.is-RM market-OBL-IN "There were many people at the market"

Domari, like Arabic and Kurdish, does not have at its disposal a verb in predicative possessive constructions. For this purpose, it uses the same morpheme as existential clauses. It is therefore more convincing to consider possessive clauses in Domari an extension of existential clauses. These are non-verbal clauses involving two NP's. The possessed entity fills the one-place 
argument of the existential predicate, whereas the possessor appears as an NP marked as an oblique and is encoded by way of adessive marking or comitative marking. The oblique NP is marked for adessive to express general possession, while comitative marking is restricted to cases when there is direct or physical contact between the possessor and the possessee. The clause may be introduced by the existential morpheme ašti (34a), or the copula cliticises to the NP encoding the possessee $(34 \mathrm{~b}, \mathrm{c})$. Whether the possessor is a proform or a full NP, two patterns are found: direct case marking on the phrase encoding the possessor $(34 a, b, e)$, or the use of a preposition-like morpheme coreferencing the possessor $(34 \mathrm{c}, \mathrm{d})$. Note that reduncy in first person marking in (34e) is triggered by the kinship term bāb "father".

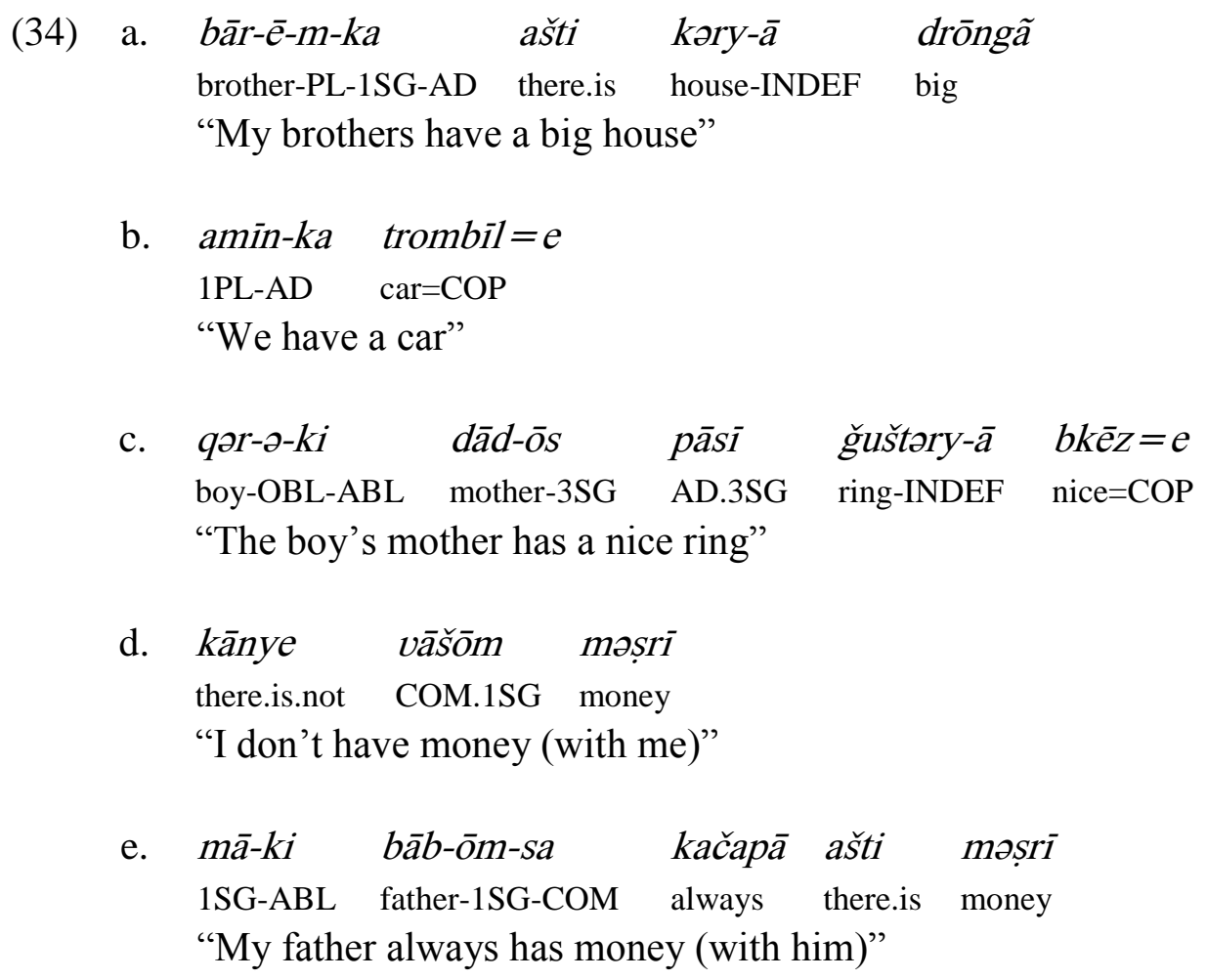

Such a variety of patterns is best explained by contact. The syntax of possessive constructions in Aleppo Domari closely resembles what is found in Kurdish, in which the possessor appears in the oblique case, and the possessee is encoded as the one-place argument of an existential clause, whereas the semantics are obviously replicated from Arabic where comitative marking is used for direct contact and adessive for general possession.

\section{Negation Strategies}

The main morpheme used to mark negation in the dialect of Aleppo is the prefix $n$-. It attaches to the verbal word: $n$-dakərdōs-əm "he didn't see me". A peculiarity appears with the tense markers -e and $-\bar{a}(\breve{s} i)$ which receive stress when $n$-is prefixed. Compare ǧān-óm-e "I know" vs. n-ğāan-mé "I don't know"; mangî́štōre "you want" vs. n-manǧǐštōré “you don’t want". Palestinian Domari exhibits a similar pattern with a stressed final element $-e^{\text {’ }}$ in the imperfective (Matras 1999:31): 
mangamsani "I like them" vs. (i)nmangamsane" "I don't like them". Initial $n$ - may drop and $-e$ ' alone suffices to mark negation: piyame "I don't drink". This is unattested in Aleppo Domari where $n$ - never drops. It is premature to say which of Aleppo Domari or Palestinian Domari innovated as far as the final glottal stop is concerned. Aleppo Domari may have lost it, or it arose as an epenthetic element in Palestinian Domari, possibly to compensate the loss of initial $n$-. As mentioned above, in complex verbs, the negation marker is normally carried by the light verb: lvā n-karme "I don't open". The prefix $m$ - is restricted to the imperative and the subjunctive: moxaztī "don't laugh!", mə-vāy-ōm "don't hit me!". In the subjunctive, the prefix $m$ - is also selected: kā mə-kənčəm "I will not go out" (FUT NEG-go.out.SUBJ.1SG). With complex verbs, $m$ - was recorded prefixed to the light verb $z^{\prime} \partial 1 \mathrm{~m}-(h) \bar{o} t \bar{i}$ "don't be upset!", and to the left bound of the verbal phrase: mo-ǧib kar “don't speak!". ${ }^{46}$ The copula is normally negated with $n$ - and stress expectedly falls on the contextualising marker: tō êta n-ištōr-é "You are not here". In the 3SG, a geminated form was recorded: $d \bar{\imath}$ dūr nonny-é "the village is not far away" (village far NEG.COP.3SG-CM), èta nənny-āši "he was not here" (here NEG.COP.3SG-RM). In existential constructions, the morpheme kānyé "there is not" is used: kānye zāvr-ōs-mã dānd "there is no tooth in his mouth" (there.is.not mouth-3SG-IN tooth), kānye pāsī bār "(s)he doesn't have any brother" (there.is.not AD.3SG brother), kānye vāšōm moṣrī bū īsom "I don't have much money right now" (there.is.not COM.3SG money much now). There are other morphemes linked to negation such as the indefinites kwāmōr "anybody" and kyāmōr "anything": kyāmōr no-hrã "nothing happened". The form kwāmōrón "nobody" was also recorded once: kwāmōrón nəsondōs-əm "nobody heard me". Interestingly, the unmarked form kāmōr can be used for both "anything" and "anybody": kāmōr no-tōs-om moșrī "nobody gave me money" (nobody NEGgive.PFV.3SG-1SG money), nə-mānde pāsōm kāmōr bdēm-or iyyā' "I don't have anything left to give you" (NEG-remain.PFV.3SG COM.1SG anything give.SUBJ.1SG-2SG OBJ.3SG). In object position, also frequent is the form kulka "nothing": kulka n-karre "he doesn't do anything" (nothing NEG-do.IMPFV.3SG). The Arabic negator mā was never recorded. The only negational morpheme borrowed from Arabic is wala. It appears in Domari only as a nominal modifier and seems to compete with the suffix -mōr (see 2.16.). In Arabic, wala is also used in contrastive negative coordination (lā...wala "neither...nor"). In such constructions, Aleppo Domari employs nə-...nə-: n-amā nə-bēn-ōm "Neither me nor my sister", nə-hnū nə-bār-ōs "neither him nor his brother".

\section{Remarks about Complex Sentences}

Aleppo Domari draws on both internal and external resources as far as clause combining is concerned. Internal embedding (relativisation and complementation) involves morphemes borrowed from Arabic, whereas external embedding (adverbial clauses) makes use of Arabic, Kurdish and inherited material.

\footnotetext{
${ }^{46}$ The same variation was observed in the dialect of Sarāqib: mə-ğib kar and ǧib mə-kar were equally accepted. The dialect of Beirut differs in this respect and generalised the marking of the leftmost position of the verbal phrase: $m ə$ $z^{\prime}$ 'l (h) $\bar{o}$ " “don't be upset".
} 


\subsection{Internal embedding}

Domari has replicated the Arabic relativisation strategy. The Arabic relativiser illi is used to introduce relative clauses and appears at the left of the relative clause. The relative clause is placed post-nominally. As in Arabic, illi is used only when the modified noun is definite. In Arabic, definition is overtly marked, mostly by way of the article $i t$. This is not available in Domari, so the use of the relativiser will itself denote the definite feature of the modified noun (35a). It seems, however, that under the pressure exerted by Arabic, some speakers feel the need to overtly mark the noun for definition. One of the most predictable ways of doing this is to recruit a demonstrative (35b). The absence of relativiser indicates that the modified noun is indefinite (35c).

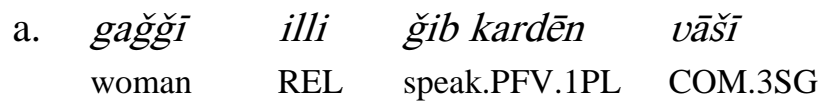
"The woman we spoke with"
b. hā tâ̄wlã illi matbax-ə-m=e
DEM table REL kitchen-OBL-IN=COP.3SG
"The table which is in the kitchen"
c. fomm ōme har gālã ğgib kar-r-os-e understand.IMPFV.1SG each word speak.IMPFV-SUB.3SG-OBJ.3SG-CM "I understand every word he says"

Languages whose main relativisation strategy is the resumptive pronoun strategy usually don't exhibit any restrictions and all syntactic positions are eligible for relativisation (Creissels 2006, Vol. II: 216). This is the case of Arabic. Since in Domari, the relativisation strategy was replicated wholesale from Arabic, it appears that in Aleppo Domari, all syntactic roles are eligible for relativisation. It should also be added that the Iranian relativiser $k e$ was recorded once: $h \bar{a}$ narrn =e ke ayrãa "This is the man who came" (DEM man=COP REL come.PFV.3SG).

As far as complementation is concerned, Aleppo Domari makes use of the Arabic complementiser inno, as shown in (36a). However, the most common strategy seems to be parataxis (36b).
a. $\quad h \bar{a} \quad k a(\check{g}) \check{g} \tilde{a}$
ğānìre
DEM man be.known.PFV.3SG
"It is known that this man is rich"
hear.PROG.1SG water want.PROG.2SG
"I hear (that) you want water"
b. snīštōme pānī mangīštōre

inno zangīl $=e$

COMP rich=COP.3SG 
The complementiser inno in Arabic often appears augmented by a bound pronoun indexing the subject of the embedded clause (inn-i "that I", inn-ak "that you"). This appears to be impossible in Aleppo Domari and the complementiser is always invariable.

\subsection{External embedding}

Adverbial clauses are mainly introduced by way of conjunctions borrowed from Arabic: lamma limmin "when", li'anno li'anni "because", bass "as soon as", qabəl-mā "before" (often reduced to qabmā), ba`əd-mā "after" (realised ba`mma), ahsan-mā "in order not to". More puzzling is the form waxti "when", which ultimately comes from Arabic waqt "time" but which may well have been borrowed from Western Iranian: waxti čăg $=i s ̌ t o m-\bar{a}$ "when I was a boy" (when boy=COP.1SG-RM). An interesting case of intertwining of morphemes borrowed from Arabic and Kurdish occurs in the complex conjunction har-mā"everytime (that)", as exemplified in (37). The pattern was replicated from Arabic kull-mā, composed of kull "each, all" and the indefinite relativiser mā. Matter was taken from Kurdish har "each" and Arabic -mā. ${ }^{47}$
har-māa $\quad$ xāzome $\quad h \bar{a} \quad h(\bar{a}) r \tilde{a} \quad s \tilde{a} \quad$ sonr-əm-e (sorróme)
every-REL laugh.IMPFV.1SG DEM neighbourhood all hear.IMPFV.3SG-OBJ.1SG-CM
"Everytime I laugh, this entire neighbourhood can hear me"

To introduce purpose subordinate clauses, several options emerge. The use of the subjunctive may suffice (38a), but more often Aleppo Domari uses conjunctions borrowed from Arabic such as mšān "in order to" or more frequently tā "until, in order to" (38b). It should be noted that the form ta may not have been borrowed from Arabic as it is appears also in neighbouring languages. Undocumented in Domari so far is tâke that combines tā and the Iranian complementiser $\mathrm{ke}(38 \mathrm{c}){ }^{48}$
a. $k$
ğām
dikkān-ə-ki pārom $\begin{array}{lll}\text { qāyī̌s } & \bar{a} r a ̄ t-\curvearrowright & k \bar{e} r a ̃ a \\ \text { food } & \text { night-OBL } & \text { for }\end{array}$ FUT go.SUBJ.1SG shop-OBL-ABL buy.SUBJ.1SG "I'll go to the shop to buy food for the night"
b. āyrã pāsōm tā ǧib karor vāšōm come.PFV.3SG AD.1SG to speak.SUBJ.3SG COM.1SG

"He came to my place to speak with me"

\begin{tabular}{|c|c|c|c|c|}
\hline $\begin{array}{l}\text { čăg } \dot{g}-\partial S \\
\text { kid-ACC }\end{array}$ & $\begin{array}{l}\text { vēsnāre } \\
\text { make sit IMPFV 3SG }\end{array}$ & $\begin{array}{l}\text { kirsiy-ē-tã } \\
\text { chair-OBL-SUP }\end{array}$ & $\begin{array}{l}\text { tāke } \\
\text { to }\end{array}$ & $\begin{array}{l}\text { qaynār-əS } \\
\text { feed SUBJ 3SG-3SG }\end{array}$ \\
\hline
\end{tabular}

"She puts the kid on the chair to feed him"

\footnotetext{
${ }^{47}$ Interestingly, in Sarāib Domari, har alone is used, whereas Beirut Domari simply uses Arabic kull-mā. It appears thus as a continuum from Kurdish to Arabic: har, har-mā, kull-mā.

${ }^{48}$ Reflexes of tāke are common in Iranian languages. Kurmanji exhibits daku "in order to", while tâke is found in Persian.
} 
Also undocumented and a bit more eccentric is the disjunction of tāke: the formative tā introduces the purpose clause, and $k e$ is placed right after the predicate (39a and 39b). This pattern was recorded quite a few a times so it appears to be a common strategy to introduce purpose clauses in Aleppo Domari. I am not aware of anything similar in neighbouring languages.
a. hã
$k a(\check{g}) \check{g} \tilde{a}$
ǧānīre
inno zangīl $=e$
DEM man
be.known.PFV.3SG
COMP rich=COP.3SG

"It is known that this man is rich"

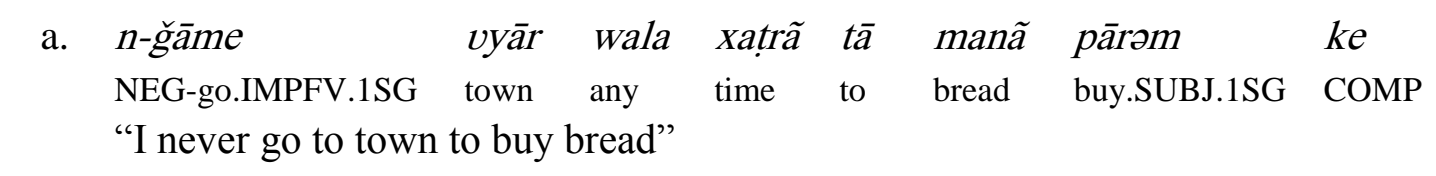
b. āyrã pāsōm tā dakčsr-om ke come.PFV.3SG AD.1SG to see.SUBJ.3SG-1SG COMP

"He came to my place to see me"

As far as conditional clauses are concerned, Aleppo Domari borrowed all the Arabic conjunctions. These are mainly iza, law and more marginally lawinn "even if". The conjunction iza introduces real conditional clause, while law is used with unreal conditionals. The use of the perfective or the imperfective is a complex matter in Arabic grammar but it can be summarised saying that the perfective denotes a higher degree of hypotheticality. The perfective is also often used to denote punctual aspect. Since Aleppo Domari borrowed all its conjunctions from Arabic and also exhibits a split between perfective and imperfective, it is very likely that they share the same use patterns. The following sentences illustrate the use of the Arabic conjunctions. The use of the perfective in (40a) seems to suggest that the speaker places the event higher on the scale of hypotheticality. The Arabic verb kān "he was" is often used in both the conditional clause and in the main clause. In many varieties of Levantine Arabic, kān lexicalised into an uninflected counterfactual particle. It comes thus as no surprise that it was borrowed as such into Aleppo Domari (40c). The Arabic conjunction lawinn- "even if" to which a bound pronoun indexing the subject of the subordinate clause often attaches, was also borrowed into Domari and appears invariably as lawinn (40d).
a. iza āyrōr lakar-m-ər-e
If come.PFV see.IMPFV-SUB.1SG-OBJ.2SG-CM
"If you come, I'll see you"
b. iza qāme toll(a) (h)ōme
if eat.IMPFV.1SG fat become.IMPFV.1SG
"If I eat I get fat"



$\begin{array}{ll}\text { c. } & \text { law } \\ \text { if } & \text { you }\end{array}$
$\bar{a} y r o \bar{r} r$
$x ə \check{g} \tilde{a}$
$k \bar{a} n$
lakərdōr-sā
If you had come yesterday you would have seen them
see.PFV.2SG-3PL

d. lāzim ğāa ōta lawinn no-mangīštōre

must go.SUBJ.2SG there even.if NEG-want.IMPFV.2SG

"You have to go there even if you don't want to"

Besides the total replication of Arabic conditionals, it appears that Aleppo Domari had at its disposal another strategy, consisting of the attachment of $s a$ to the right of the verb, both in the perfective (41a) and the imperfective (41b). Prosodically, sa remains unstressed: lakordós $=s a(<$ lakərdōr=sa) "if you see"; mangīštōré= sa "if you want", suggesting it is best seen as a clitic.
a. lakordōs $=s a \quad$ kyāmōr $\quad$ ğib kar vāšōm see.PFV.2SG=if something speak.IMP COM.1SG
"If you see something, speak to me"
b. $s a k \bar{e}=s a \quad p \bar{a} \quad p \bar{a} s \bar{o} m$
can.IMPFV.2SG=if come.IMP AD.1SG
"If you can, come to my place"

The morpheme $s a$ in Domari is obviously a case of matter replication from the Turkish suffix $s A$. In Turkish, $-s A$ also attaches to the predicate. ${ }^{49}$ It should be added however, that Turkish $-s A$ is frequently borrowed into Kurdish dialects in contact with Turkish, ${ }^{50}$ so it may well have been borrowed from Kurdish and not directly from Turkish. Also puzzling is the fact that sa in Aleppo Domari was only recorded in the $2 \mathrm{SG}$. For other persons, only Arabic conjunctions were recorded. One may conceive that the clitisation of sa was once the main strategy. While Arabic conjunctions were making their way into Aleppo Domari, sa remained restricted to $2 \mathrm{SG}$ forms. It is of course unclear why the $2 \mathrm{SG}$ and not other persons. ${ }^{51}$

The most obvious example for which Aleppo Domari draws on internal resources is the way of expressing simultaneity. The most common strategy seems to be by way of the conjunctionlike complex morpheme hōši (glossed here "as"). The verb of the subordinate clause was recorded with the progressive stem (42a) or in the imperfective (42b).

\begin{tabular}{|c|c|c|}
\hline $\begin{array}{l}\text { slālã } \\
\text { rain }\end{array}$ & $\begin{array}{l}\text { (h)rã } \\
\text { become.PFV.3SG }\end{array}$ & $\begin{array}{ll}\text { vatōmāa } h \bar{o} s \overline{1} \\
\text { SUP.1PL }\end{array}$ \\
\hline
\end{tabular}

\footnotetext{
${ }^{49}$ This can be a verb or a copula, see Göksel \& Kerslake (2005:419).

${ }^{50}$ See for that matter Bulut (2006:107-108) and Haig (2007:173).

${ }^{51}$ Such a restriction does not exist in the Domari dialect of Sarāqib in which sa can attach to any person. The dialect of Beirut only exhibits Arabic conjunctions.
} 


\section{b. hōšn manderdende āyrōs-sā bōğy-ā \\ as stand.IMPFV.3PL come.PFV.3SG-OBJ.3PL dog-INDEF \\ "As they were standing, a dog came to them"}

The morpheme hōšĩ seems to be composed of the formatives $h \bar{o}$ and $\breve{s} \bar{l}$. The former is most probably a short form of the imperfective of the verb $h$ - "become", while the latter is the clitic $\check{S} \overline{1}^{-}$ "also, and". The clitic š̃ is most likely to have been borrowed from Kurdish where a very similar morpheme, both in form and function is reported. ${ }^{52}$ In Aleppo Domari, š̄ attaches to the right bound of the constituent. It is used as a focus particle (43a) or to coordinate different constituents, such as verbal phrases (43b), but also clausal constituents (43c).
a. tō= ̌̌i yēlkānī (h)rōre dūnōm
2SG=too alone become.PFV.2SG without.1SG
"You too, you are lonely without me"
b. kəčmārīn mangənde vēštond kəry-ə vāgər old.PL like.IMPFV.3PL stay.SUBJ.3PL home-OBL in.front.of
$\begin{array}{ll}\text { ǧib karənd }=\check{S} \bar{i} & b \bar{u} \\ \text { speak.SUBJ.3PL=and } & \text { much }\end{array}$
"Old people like to stay in front of the house and speak a lot"

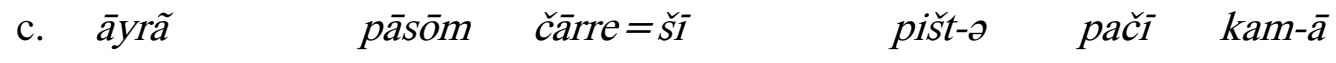
come.PFV.3SG AD.1SG hide.IMPFV.3SG=and back-OBL behind thing-INDEF
"He came to me (and was) hiding something behind his back"

Technically speaking, (43c) does not pertain to subordination but rather to coordination. Formally though, hōši clauses appear to be an extension of the pattern exhibited in (43c), in which two clausal constituents are coordinated with the clitic šĭ. It is very plausible that hōš clauses are in fact an instance of contact-induced grammaticalisation whereby Domari replicated what is commonly called in Arabic grammar hāl clauses. These are subordinated clauses expressing simultaneity, introduced by the coordination particle $W^{-}$"and", itself followed by a free pronoun: $W$ ana walad "when I was a kid" (and 1SG kid). While the replication of Arabic $W$ through the clitic $\check{S} \overline{1}$ is rather straightforward, more puzzling is the origin of the formative $h \bar{o}$-. It was suggested above that it may be a short form of the imperfective of the verb $h$ - "become". One possibility is that the Arabic free pronoun in $h \bar{a} l$ constructions was interpreted as a copula, and so replicated by way of $h$-. The origin of $h \overline{o s} \bar{s}$ clauses could then be explained by an extension of the clausal complements coordinated with $=\check{S} \bar{i}$ triggered by the contact-induced grammaticalisation of Arabic $h \bar{a} l$ clauses, leading to the emergence of a new subordination conjunction.

\footnotetext{
${ }^{52}$ Mokri (2003:611-612) gives the following forms: $-i \check{c} /-y \check{c} /-i \check{S} /-i \check{S}$, and translates it (in French) "aussi, également".
} 


\section{Conclusion}

Until recently, everything that was known about Domari relied on Palestinian Domari, a now moribund dialect first investigated in the beginning of last century by R.A.S. Macalister (1914) and subsequently by Yaron Matras (1999) who sketched the present state of the same dialect as spoken by the remaining community in Jerusalem. Apart from these two sources and a couple of word lists dating back from the $19^{\text {th }}$ century, no description is available for other varieties. This paper aimed at filling in this gap by presenting first-hand linguistic data about an undescribed variety of Domari. The most striking feature of Aleppo Domari compared to Palestinian Domari is the loss of gender as an inflectional category. This, as shown above, had an impact on a series of paradigms. Most conspicuous is the restructuring of Layer I case marking with the generalisation of the masculine - $a$ s as a general accusative marker and feminine $-a$ as a general oblique marker. Another category that has been restructured due to gender neutralisation is that of the demonstratives. When compared to Palestinian Domari, one notices the loss of the feminine form $\bar{i} h \bar{i}$ and the reassignment of oblique forms $\bar{e} r$ - and $\bar{o} r$ - to anaphoric demonstratives. One last category on which gender neutralisation had an impact is the form of the 3SG perfective for which the masculine form was generalised (Aleppo garã "(s)he went" vs. Palestinian gara "he went" - gari "she went"). Case marking in Aleppo Domari, besides the restructuring of Layer I markers, does not exhibit any eccentric idiosyncrasy. Layer II markers show important differences both in forms and functions. While in all documented varieties, the ablative marker ki extended to a prepositional case, Aleppo Domari also further extended it to what may be called a motative marker, encoding not only origin but also destination. Such a development makes it difficult to keep the term 'ablative' to designate the marker -ki. Undocumented so far was the versative marker - va "towards", used in Aleppo, and in the dialects of Sarāqib and Beirut. Aleppo Domari stands apart, allocating of a set of relational nouns expressing mainly spatial relations (benefactive -kērã being an exception). Diachronically, these relational nouns are also good candidates for the emergence of Layer II markers, through erosion and structural integration to the modified noun. The appearance of the oblique marker in such constructions indicates that the oblique marker in Aleppo Domari partially kept its original function of genitive marker (Matras 2002:174). This is apparent in phrases like dōm-ə ǧib "the language of the Dōm" (Dōm-OBL language), halab-ə dōm "the Dōm of Aleppo" (Aleppo-OBL Dōm). Also peculiar to Aleppo Domari is the ongoing grammaticalisation of the noun xor "heart" from a relational noun expressing location to a Layer II marker. Aleppo Domari has remained rather modest as far borrowing of prepositions is concerned. None of the core prepositions of Arabic made their way into the grammar of the language, and only the core Iranian preposition $z$ - "from" was replicated. This preposition appears to be an old borrowing and must be well entrenched into the language as the morpheme already appears in sources from the $19^{\text {th }}$ century. As far as the verb phrase is concerned, a peculiarity most probably shared by all northern varieties, is the extension -št- to derive stems denoting progressive aspect. Another interesting morpheme is the future marker $k \bar{a}$ which evolved from a pseudo-verb of volition $k \bar{a} r$-. It was suggested that Domari $k \bar{a}$ and Balkan Romani $\mathrm{ka}$ most probably result from separate developments. Aleppo Domari is also conservative as far as complex verbs are concerned as there are almost no signs of integration 
between the lexical element and the light verb, contrary to other varieties in which integration is much more developed. As far as syntactic typology is concerned, Aleppo Domari displays a rather conservative pattern, having preserved to a certain extent the modifier-head order. One exception to this is the incipient convergence towards Arabic constituent order in noun-adjective constructions. Constituent order at clausal level seems to be quite free in Aleppo Domari. A detailed analysis is beyond the scope of this study but one example may illustrate the freedom exhibited in constituent order:

$\begin{array}{llllll}\check{c} \bar{a} \bar{g} \text {-ən } & \text { har } & \text { dīs } & \text { səknāre } & \text { harf-ā } & \text { ustāz } \\ \text { child-ACC.PL } & \text { each } & \text { day } & \text { teach.IMPFV.3SG } & \text { letter-INDEF } & \text { teacher }\end{array}$

"Every day, the teacher teaches a new letter to the kids"

As far as other grammatical borrowings are concerned, ${ }^{53}$ the numerals are inherited or borrowed from Kurdish. The only Arabic element that surfaces is in the expression of "ninety": sadd illa dazz, literally "hundred (Kurdish) except (Arabic) ten (inherited)". Amongst the modal verbs and auxiliary, only lāzim "must" was borrowed from Arabic. Arabic inflections and negator are not replicated. Comparative and superlative initially draw on Kurdish and Turkish, and only marginally on Arabic. Focus particles do not draw on Arabic ( ̌̌̆ "and, also", gēna "also"), neither do indefinites. Categories largely replicated from Arabic are conjunctions, the complementiser inno, the relativiser illi, discourse markers (ba'dēn "afterwards", ya'ni "that is to say" awwal š "first of all", xalaṣ "that's it") while phasal adverbs are not Arabic (nə-mānde "no more", hazzi "yet", although Arabic lissa "still, yet" was recorded). The syntactic typology remains quite free of any Arabic influence. The overall picture is that, while influenced by Arabic in several areas, Kurdish and other varieties of Iranian also had a sizeable impact. It should also be added that the influence of Kurdish may still be ongoing as many Dōm in Aleppo maintain a good level of proficiency in Kurdish, as they share their neighbourhood with Kurds.

\section{Abbreviations}

$\begin{array}{ll}\text { ABL } & \text { Ablative } \\ \text { ACC } & \text { Accusative } \\ \text { AD } & \text { Adessive } \\ \text { CAUS } & \text { Causative } \\ \text { CM } & \text { Contextualising marker } \\ \text { COM } & \text { Comitative } \\ \text { COMP } & \text { Complementiser } \\ \text { COP } & \text { Copula } \\ \text { COUNT } & \text { Counterfactual } \\ \text { DEF } & \text { Definite } \\ \text { DEM } & \text { demonstrative } \\ \text { FUT } & \text { Future marker }\end{array}$

\footnotetext{
${ }^{53}$ See Matras (2005) for a summarised analysis of the Arabic component in contemporary Palestinian Domari.
} 


$\begin{array}{ll}\text { IMP } & \text { Imperative } \\ \text { IMPFV } & \text { Imperfective } \\ \text { IN } & \text { Inessive } \\ \text { INDEF } & \text { Indefinite } \\ \text { INSTR } & \text { Instrumental } \\ \text { NEG } & \text { Negation } \\ \text { OBJ } & \text { Object } \\ \text { OBL } & \text { Oblique } \\ \text { PASS } & \text { Passive } \\ \text { PRF } & \text { Perfect } \\ \text { PFV } & \text { Perfective } \\ \text { PROG } & \text { Progressive } \\ \text { REFL } & \text { Reflexive } \\ \text { REL } & \text { Relativiser } \\ \text { RM } & \text { Remoteness marker } \\ \text { SUB } & \text { Subject } \\ \text { SUBJ } & \text { Subjunctive } \\ \text { SUP } & \text { Superessive } \\ \text { VERS } & \text { Versative }\end{array}$

\section{References}

Al-Jibāwī, 'Alī. 2006. 'ašă'ir al-nawar fỉ bilād al-šăm [Gypsy clans in the Levant]. Damascus: Al-Takwin.

Beníšek, Michael. References to the Dombas in Rājataraniginī. Oriental Archive 77, 349-366. Boretzky, Norbert. 2003. Die Vlach-Dialekte des Romani. Wiesbaden: Harrassowitz Verlag. Bulut, Christiane. 2006. Turkish elements in spoken Kurmanji. L. Johanson \& C. Bulut, TurkicIranian Contact Areas. Wiesbaden: Harrassowitz Verlag, 95-121.

Comrie, Bernard. 1976. Aspect. Cambridge: Cambridge University Press.

Creissels, Denis. 2006. Syntaxe générale, une introduction typologique. Paris: Lavoisier (Vol. I \& II).

----. 2009. Spatial cases. A. Malchukov \& A. Spencer (eds.), 2009, The Oxford Handbook of Case. Oxford: Oxford University Press, 609-625.

Elšík, Viktor \& Matras, Yaron. 2001. Romani dialectological questionnaire. Department of Linguistics, University of Manchester

----- 2006. Markness and language change: the Romani sample. Berlin: de Gruyter.

Göksel, Aslı \& Kerslake, Celia. 2005. Turkish: A Comprehensive Grammar. London: Routledge. Groome, Francis. 1891. Persian and Syrian Gypsies. Journal of the Gypsy Lore Society 2, 21-27. Haig, Geoffrey. 2006. Turkish influence on Kurmanji: Evidence from the Tunceli dialect. L. Johanson \& C. Bulut, Turkic-Iranian Contact Areas. Wiesbaden: Harrassowitz Verlag, 283299

----- 2007. Grammatical borrowing in Kurdish (Northern Group). Y. Matras and J. Sakel (eds) Grammatical borrowing in cross-linguistic perspective. Berlin: de Gruyter, 165-184. 
Heine \& Kuteva. 2005. Language Contact and Grammatical Change. Cambridge: Cambridge University Press.

Koul, Omkar N. 2008. Modern Hindi Grammar. Hyattsville: Dunwoody Press.

Koul, Omkar N. \& Wali, Kashi. 2006. Modern Kashmiri Grammar. Hyattsville: Dunwoody Press.

Kutscher \& Genç. 2006. On depictive secondary predicates in Laz. Nikolaus P. Himmelmann \& Eva Schultze-Berndt (eds), Secondary predication and adverbial modification: the typology of depictives. Oxford: Oxford University Press, 237-258.

Lazard, Gilbert. 1998. Actancy. Berlin: de Gruyter.

Lorimer, David Lockhart Robertson. 1939. The Dumāki Language. Outlines of the Speech of the Doma, or Bērīcho, of Hunza. Nijmegen: Decker \& van de Vegt N.V.

Macalister, R. A. S. 1914. The language of the Nawar or Zutt, the nomad smiths of Palestine. (Gypsy Lore Society Monographs 3.) London: Edinburgh University Press.

Masica, Colin P. 1991. The Indo-Aryan Languages. Cambridge: Cambridge University Press. Matras, Yaron. 1999. The State of Present Day Domari in Jerusalem. Mediterranean Language Review 11, 1-58.

----. 2000. Two Domari legends about the origin of the Doms. Romani Studies 5 (10), 53-79.

----. 2002. Romani. A Linguistic Introduction. Cambridge: Cambridge University Press

----. 2005. The full extent of fusion: A test case for connectivity and language contact. W. Bisang, T. Bierschenk, D. Kreikenbom \& U. Verhoeven (eds). Kulturelle und sprachliche Kontakte: Prozesse des Wandels in historischen Spannungsfeldern Nordostafrikas/Westasiens. Würzburg: Ergon Verlag, 241-255.

----- 2006. Gypsy Arabic. Encyclopedia of Arabic Language and Linguistics, Volume II. Leiden: Brill, 216-222.

----. 2007. Grammatical borrowing in Domari. Matras, Yaron \& Sakel, Jeanette (eds). Grammatical Borrowing in a cross-linguistic Perspective. Berlin: de Gruyter, 151-164.

----. 2009. Defining the limits of grammatical borrowing. Marcantonio, Angela. (ed). The IndoEuropean language family: Questions about its status (Monograph series n. 55 of Journal of Indo-European Studies).

----. 2009a. Language Contact. Cambridge: Cambridge University Press.

McCarus, Ernest. 2009. Kurdish. Windfuhr, Gernot (ed). The Iranian Languages. London and New-York: Routledge, 587-633.

Meyer, Frank. 1994. Dōm und Turkmān in Stadt und Land Damaskus. Erlangen: Fränkische Geographische Gesellschaft.

----. 2004. "Biography and Identity in Damascus: A Syrian Nawar Chief". In Joseph Berland \& Aparna Rao (eds.) Customary Strangers. New Perspectives on Peripatetic Peoples in the Middle-East, Africa, and Asia. Santa Barbara: Greenwood Publishing Group. 71-92.

Mokri, Mohammad. 2003. Grammaire et Lexique comparés des dialects kurdes : éléments de linguistique iranienne. Paris: Karthala

Newbold, F.R.S. 1856. The Gypsies of Egypt. Journal of the Royal Asiatic Society of Great Britain and Ireland 16, 285-312.

Oranskij, I.M. 1977. Folklor i jazyk gissarskixParja Sredneja Azija. Moscow: Akademija Nauk. 
Ouseley, William. 1823. Travels in Various Countries of the East; more particularly Persia. London: Rodwell and Martin.

Patkanoff, K.P. 1907/1908. Some words on the dialects of the Transcaucasian Gypsies. Journal of the Gypsy Lore Society, new series, 1, 229-257; 2, 246-266, 325-334

Paspati, Alexandre G. 1870. Etudes sur les Tchinghianés ou Bohémiens de l'Empire Ottoman. Constantinople: Antoine Koroméla.

Payne, John R. 1997. The Central Asian Parya. Akiner, Shirin and Nicholas Sims-Williams (eds), Languages and scripts of Central Asia. London: SOAS, 144-153.

Pott, August. 1846. Über die Sprache der Zigeuner in Syrien. Zeitschrift für die Wissenschaft der Sprache 1, 175-186.

Rao, Aparna. 1985. Des Nomades méconnus. Pour une typologie des communautés péripatétiques. L'Homme 25(95), 97-120.

Schultze-Berndt, Eva. 2004. Taking a closer look at function verbs: lexicon, grammar, or both?. F.K. Ameka, A. Dench, and N. Evans (eds.), Catching Language. The Standing Challenge of Grammar Writing. Berlin: de Gruyter, 359-391.

Tsunoda, Tasaku. 1985. Remarks on transitivity. Journal of Linguistics 21 (2), 385-396.

Turner, R. L. (Ralph Lilley), Sir. A comparative dictionary of Indo-Aryan languages. London: Oxford University Press, 1962-1966. Includes three supplements, published 1969-1985

Voskanian, Vardan. 2002. The Iranian Loan-Words in Lomavren, The Secret Language of the Armenian Gypsies. Iran \& the Caucasus. Vol. 6, No. 1/2 (2002), 169-180.

Weinreich, Matthias. 1999. Der Domaakí-Dialekt von Nager. Studien zur Indologie und Iranistik 22, 203-214.

-----. 2008. Two Varieties of Domaakí. Zeitschrift der Deutschen Morgenländischen Gesellschaft 158, 299-316.

Wohlgemuth, Jan. 2009. A Typology of Verbal Borrowings. Mouton de Gruyter.

Zoller, Claus Peter. 2005. A Grammar and Dictionary of Indus Kohistani. Volume 1: Dictionary. Berlin: de Gruyter.

-----. 2010. Aspects of the Early History of Romani. Acta Orientalia 71, 243-312.

Author's Contact Information:

Bruno Herin

Campus du Solbosch - CP110,

50 Avenue F.D. Roosevelt, 1050 Brussels (Belgium)

Bruno.Herin@ulb.ac.be 